4 nordon 



\section{Literature Review on Residues of Anticoagulant Rodenticides in Non-Target Animals}

Senja Laakso, Kati Suomalainen and Sanna Koivisto

TemaNord 2010:541 


\section{Literature Review on Residues of Anticoagulant Rodenticides in Non-Target Animals}

TemaNord 2010:541

(C) Nordic Council of Ministers, Copenhagen 2010

ISBN 978-92-893-2063-4

This publication is available as Print on Demand (PoD) and can be ordered on

www.norden.org/order. Other Nordic publications are available at www.norden.org/en/publications.

Nordic Council of Ministers

Store Strandstræde 18

DK-1255 Copenhagen K

Phone (+45) 33960200

Fax (+45) 33960202

www.norden.org

\section{Nordic Council}

Store Strandstræde 18

DK-1255 Copenhagen K

Phone (+45) 33960400

Fax (+45) 33111870

\section{Nordic co-operation}

Nordic co-operation is one of the world's most extensive forms of regional collaboration, involving Denmark, Finland, Iceland, Norway, Sweden, and three autonomous areas: the Faroe Islands, Greenland, and Åland.

Nordic co-operation has firm traditions in politics, the economy, and culture. It plays an important role in European and international collaboration, and aims at creating a strong Nordic community in $\varepsilon$ strong Europe.

Nordic co-operation seeks to safeguard Nordic and regional interests and principles in the global community. Common Nordic values help the region solidify its position as one of the world's most innovative and competitive. 


\section{Contents}

Preface

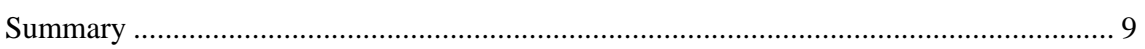

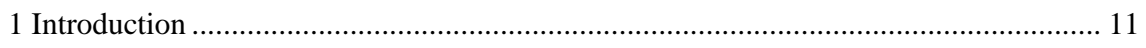

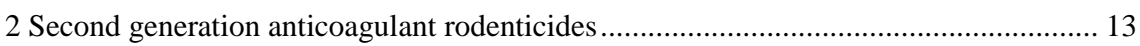

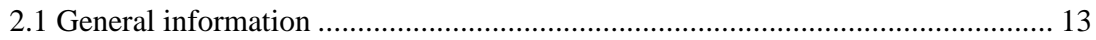

2.2 Mode of action, symptoms and toxicity ……................................................. 14

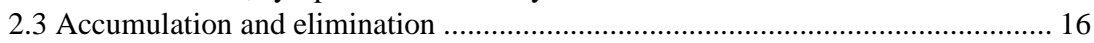

2.4 Secondary exposure of non-target species........................................................... 20

3 Review on studies on anticoagulant secondary poisoning in wildlife............................. 25

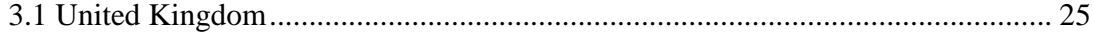

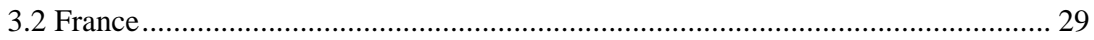

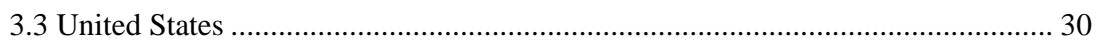

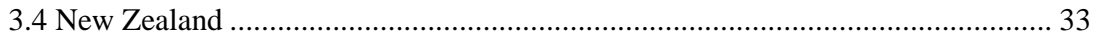

4 Conclusions and implications to the Nordic countries.................................................. 35

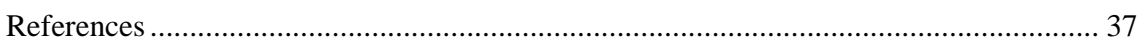

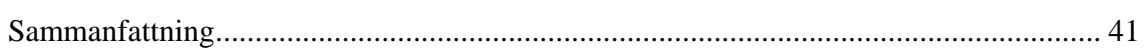

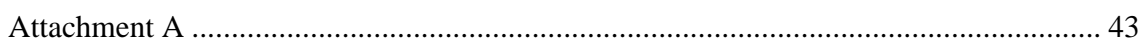

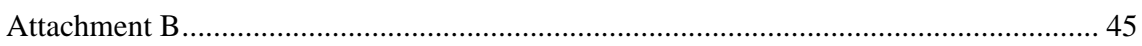





\section{Preface}

Anticoagulant rodenticides are the principal means of controlling pest rodents in the Nordic countries. Due to the intrinsic properties of second generation anticoagulants, i.e. extremely slow elimination from the body and high toxicity, they are prone to accumulate in the non-target species which consume poisoned rodents. Despite wide use there are no published studies on occurrence of residues of anticoagulant rodenticides in the non-target animals in the Nordic countries. This review of publicly available studies was aimed to find out which anticoagulant substances are found and in which species. The concentrations are reported as well as the proportion of exposed animals. We have further compiled a list of species that could potentially be exposed to anticoagulant rodenticides in the Nordic countries. The review shows that anticoagulant residues have been found everywhere they have been measured and secondary exposure to second generation anticoagulants is common among certain avian and mammalian predators. The results call for initiation of measurements of anticoagulant rodenticides also in the Nordic countries.

Information on residues is important for the consideration of appropriate risk mitigation measures for the second generation anticoagulants. Several risk mitigation measures are already applied, such as restriction to indoor use or restriction to professional use only. The information on residue levels and the extent of exposure would help to judge whether the current risk mitigation measures are sufficiently effective or whether further measures or even restrictions should be considered.

The Nordic Biocide Group acted as a steering group for this review project. The authors thank Kurt Haglund, (Swedish Chemicals Agency), Solveig Aamodt, Christian Dons and Susanne Hardt (Norwegian Climate and Pollution Agency) for constructive comments on the earlier draft of the report. The work was partially funded by the Nordic Council of Ministers through the Nordic Chemicals Group. 



\section{Summary}

Residues of second generation anticoagulant rodenticides in wildlife have been found all around the world where the occurrence of residues has been investigated. Second generation anticoagulants, brodifacoum, bromadiolone, difenacoum, difethialone and flocoumafen, have been gradually introduced after the appearance of resistance to warfarin and other first generation substances. They are much more toxic and in particular more persistent in rodents and hence potent in accumulating in non-target species that feed on target and non-target rodents. Despite wide use of anticoagulants, there are relatively few studies where anticoagulant residues have been measured in non-target animals. More systematic incident studies have been done only in Britain and in some states of the US. In addition to Britain, published data on anticoagulant residues is available only in France in Europe. In Britain anticoagulant residues have been studied in particular in barn owl (Tyto alba) and in polecats (Mustela putorius). About one third of studied carcasses contained residues. In most cases, the residues were expected to be sublethal. No studies on the effects of the sublethal residues have been found. In the UK incident program other commonly exposed species were buzzard (Buteo buteo), red kite (Milvus milvus), and fox (Vulpes vulpes). In the US the commonly exposed species were great horned owls (Bubo virginianus), red-tailed hawks (Buteo jamaicensis), coyotes, foxes and raccoons. Anticoagulants are the dominant rodenticides in the Nordic countries, but no information is available on residues in non-target species. Information on residues is needed in order to judge whether the currently used risk mitigation measures are effective and whether further measures or restrictions should be considered. 



\section{Introduction}

Use of anticoagulant rodenticides is the dominating way to control undesired rodent species. The effectiveness of anticoagulants is due to the delayed mode of action which prevents rodents to connect the poisoning symptoms to the bait they have fed a few days ago. This is important in the control of rats which are cautious and avoid food which makes them ill. Anticoagulant rodenticides were introduced for the control of harmful rodents, but unfortunately non-target species are affected too, either directly through consumption of poisoned baits or indirectly through consumption of contaminated prey animals (secondary poisoning) (Lambert et al. 2007). The indirect poisoning, i.e. secondary poisoning threatens birds and mammals that feed on living or dead rodents. Secondary poisoning is most commonly associated with the second generation anticoagulants (Berny et al. 1997; Shore et al. 2003; Stone et al. 2003; Fournier-Chambrillon et al. 2004).

The aim of this literature review is to find out which substances tend to accumulate in wildlife and which species are most likely exposed to anticoagulant rodenticides, and further serve as a preliminary study for the survey of anticoagulant residues in non-target species in the Nordic countries. 



\section{Second generation anticoagulant rodenticides}

\subsection{General information}

First generation anticoagulants were introduced as rodenticides in the late 1940 's. The appearance of resistance to warfarin and other first generation substances led to the development of more potent, second generation anticoagulants (IPCS Environmental Health Criteria 175, Anticoagulant Rodenticides). The first generation anticoagulants, e.g. warfarin, sodium warfarin, chlorophacinone and coumatetralyl, are effective first after several repeated ingestions. The newer, second generation anticoagulants bromadiolone, brodifacoum, difenacoum, difethialone and flocoumafen may cause an effect already after a single ingestion and are toxic at a much lower dose than the first generation anticoagulants (Berny 2007).

Active substances used in rodenticides have been included in the review program of existing biocidal active substances (Directive 98/8/EC, Commission Regulation No 1451/2007). Nine anticoagulant rodenticides are included in the review programme and most of them are on the market in the Nordic countries (Table 1). Denmark, Finland, Norway and Sweden have been the Rapporteur Member States for coumatetralyl, difenacoum, difethialone and bromadiolone, respectively. Anticoagulants are the dominant active substances used for rodent control and in Finland they are the only rodenticides on the market. The summaries of the risk assessments (assessment reports) for anticoagulants are available on the Internet, and can be accessed from the EU Commission's web site on biocides or from the CIRCA database:

http://circa.europa.eu/Public/irc/env/bio_reports/library?l=/assessement_directive\&vm=detailed\&sb=Title (Ref. 21.10.2009).

In the risk assessment all second generation anticoagulants were identified as potential PBT substances, i.e. substances which are persistent, bioaccumulating and toxic. Such substances are problematic when released to the environment because they will stay there for a long time and could accumulate in animals. According to the Technical Notes for Guidance (TNsG) on Annex I inclusion, substances fulfilling the PBT criteria shall not be included in Annex I unless releases to the environment can be effectively prevented.

Annex I inclusion has been proposed for the evaluated anticoagulants under the directive 98/8/EC, in spite of the identified PBT properties and the risk for primary and secondary poisoning of non-target animals. Annex I inclusion has been suggested because anticoagulant rodenticides are 
regarded as necessary for public health reasons and so far equally useful, effective and less hazardous alternative substances do not exist. The main target organisms in Europe are brown rat (Rattus norvegicus), black rat (Rattus rattus), and house mouse (Mus musculus or Mus domesticus). These species have been identified as target species in the review programme. In the UK the grey squirrel (Sciurus carolinensis) is also controlled with anticoagulants (McDonald et al. 1998). Anticoagulant rodenticides are also used against voles (Microtus sp. and Arvicola sp.) in agriculture (Directive 91/414/EEC).

Table 1. Anticoagulant rodenticides and the Rapporteur Member States (RMS) in the EU review programme of existing biocidal active substances. Anticoagulants used in the Nordic countries are given according to Lodal and Hansen (2002).

\begin{tabular}{llllllll}
\hline Anticoagulant & CAS No & RMS & Denmark & Finland & Iceland & Norway & Sweden \\
\hline Warfarin & $81-81-2$ & IE & & & & $\mathrm{x}$ & $\mathrm{x}$ \\
Warfarin sodium & $129-06-6$ & IE & & & & & $\mathrm{x}$ \\
Coumatetralyl & $5836-29-3$ & DK & $\mathrm{x}$ & $\mathrm{x}$ & & $\mathrm{x}$ & $\mathrm{x}$ \\
Chlorophacinone & $3691-35-8$ & $\mathrm{ES}$ & & & $\mathrm{x}$ & & \\
Difenacoum & $56073-07-5$ & FI & $\mathrm{x}$ & $\mathrm{x}$ & $\mathrm{x}$ & $\mathrm{x}$ & $\mathrm{x}$ \\
Bromadiolone & $28772-56-7$ & SE & $\mathrm{x}$ & $\mathrm{x}$ & $\mathrm{x}$ & $\mathrm{x}$ & $\mathrm{x}$ \\
Brodifacoum & $56073-10-0$ & IT & $\mathrm{x}$ & $\mathrm{x}$ & & $\mathrm{x}$ & $\mathrm{x}$ \\
Flocoumafen & $90035-08-8$ & NL & $\mathrm{x}$ & $\mathrm{x}$ & & $\mathrm{x}$ & $\mathrm{x}$ \\
Difethialone & $104653-34-1$ & NO & $\mathrm{x}$ & $\mathrm{x}$ & & $\mathrm{x}$ & \\
\hline
\end{tabular}

The rodenticides fumarin, diphacinone and pindone, which are also mentioned in this report, are not included in the EU review programme. Only substances in the review programme and accepted in Annex I of the Directive 98/8/EC can be legally used in the EU/EEA.

\subsection{Mode of action, symptoms and toxicity}

Anticoagulant rodenticides have a common mode of action. These substances are vitamin $\mathrm{K}$ antagonists. They inhibit the vitamin K-dependent steps in the coagulation cascade in the liver, disrupting normal bloodclotting mechanisms and causing death by haemorrhage. The first generation substances are not sufficiently toxic to rodents to cause death after a single feeding, and repeated exposure is needed. Second generation products have a greater affinity to binding sites in the vertebrate liver and consequently display greater accumulation and persistence in the body (Parmar et al. 1987, in Eason et al. 2002). Elimination half-lives of 118220 days from the livers of rats have been reported for brodifacoum, bromadiolone, difenacoum and flocoumafen (Erickson \& Urban 2004). The superiority of anticoagulants compared to acute rodent poisons previously used is the delayed mode of action, rendering the target rodents unable to connect the poisoning symptoms to the bait.

The symptoms appear 3-4 days after ingestion of the bait (Lodal \& Hansen 2002). In general death results from haemorrhage 4 to 10 days after 
the intake of the bait. Anticoagulant poisoning is expressed as severe haemorrhage with massive bleeding and poor coagulation. Bleeding may be observed externally but is usually internal. Signs associated with blood loss such as anemia, pale mucous membranes, weakness, hypothermia and tachycardia, can be observed. Evidence of massive bleeding is noted at necropsy and the lack of coagulation indicates exposure to anticoagulant rodenticides. Confirmation of poisoning is obtained from analysis of blood or liver samples for the presence of coumarines (Berny 2007).

Published investigations have shown that many mustelids have detectable residues of anticoagulants in their liver, although death has been attributed by some other cause, e.g. trauma or infectious disease (Shore et al. 2003; Fournier-Chambrillon et al. 2004). Exposure to low levels of anticoagulants may have behavioural or pathological effects, and in most cases exposed animals are weak, have slower reactions and movements and are more susceptible to accidents, predation or infection (FournierChambrillon et al. 2004). Repeated sub-lethal exposures, even intermittent ones, may be expected to eventually cause fatal haemorrhage.

The LD50 value is the dose of a substance which kills 50\% of the test animals. LD50 values are used to describe the acute toxicity of a substance. An overview of the LD50 values of second generation anticoagulants for target and non-target animals are given in Table 2. Howald et al. (1999) noted that assuming an LD50 for a raven or crow of $0.56 \mathrm{mg}$ brodifacoum $/ \mathrm{kg}$ body weight and a total-body burden (meaning wholecarcass anticoagulant residues) in a rat of $1.4 \mathrm{mg}$, one poisoned rat could contain 2 to 3 times the LD50 dose for a raven or crow. A bald eagle would need to eat about 3.2 rats to obtain an LD50 dose. Rats which had consumed on average brodifacoum bait at $10.7 \mathrm{~g}$ (range 7.3-13.9 g), containing $0.54 \mathrm{mg}$ of brodifacoum (a lethal dose), died 4-6 days after poisoning (Hooker \& Innes 1995).

Liver concentrations of 1.0 to $1.9 \mathrm{mg} / \mathrm{kg}$ brodifacoum have commonly been found in rats. Concentrations between 2 to $5 \mathrm{mg} / \mathrm{kg}$ occur with a lower frequency, but even concentrations of over $7 \mathrm{mg} / \mathrm{kg}$ of brodifacoum in rat liver have been detected (Eason et al. 1999). Repeated dose studies in rats with flocoumafen have demonstrated that concentrations in the liver of rats can reach 3-5 mg/kg when lethal anticoagulant effects occur in most animals (Huckle et al. 1988). 
Table 2. LD50 values of second generation anticoagulants to target rodents and some non-target animals.

\begin{tabular}{|c|c|c|c|c|}
\hline Common name & Scientific name & Anticoagulant & LD50 mg/kg & Reference \\
\hline Pig & Sus domestica & Brodifacoum & 0.1 & Eason \& Spurr 1995 \\
\hline Rat & Rattus norvegicus & Brodifacoum & $0.24-0.39$ & $\begin{array}{l}\text { Eason et al. 2002; Stone et al. } \\
\text { 1999; Erickson \& Urban } 2004\end{array}$ \\
\hline Dog & $\begin{array}{l}\text { Canis lupus } \\
\text { familiaris }\end{array}$ & Brodifacoum & $0.25-3.5$ & $\begin{array}{l}\text { Eason \& Spurr 1995; } \\
\text { Erickson \& Urban } 2004\end{array}$ \\
\hline Mouse & Mus musculus & Brodifacoum & 0.4 & $\begin{array}{l}\text { Erickson \& Urban } 2004 \\
\text { EU risk assessment }{ }^{1}\end{array}$ \\
\hline Laboratory rat & Rattus norvegicus & Brodifacoum & $0.42-0.56$ & $\begin{array}{l}\text { Erickson \& Urban } 2004 \\
\text { EU risk assessment }{ }^{1}\end{array}$ \\
\hline Raven & Corvus corax & Brodifacoum & 0.56 & Howald et al. 1999 \\
\hline Mink & Mustela lutreola & Brodifacoum & 9.2 & Erickson \& Urban 2004 \\
\hline $\begin{array}{l}\text { Australasian } \\
\text { harrier }\end{array}$ & $\begin{array}{l}\text { Circus approxi- } \\
\text { man }\end{array}$ & Brodifacoum & 10 & Eason \& Spurr 1995 \\
\hline Cat & Felis catus & Brodifacoum & 25 & $\begin{array}{l}\text { Stone et al. 1999; } \\
\text { Erickson \& Urban } 2004\end{array}$ \\
\hline Rat & Rattus norvegicus & Bromadiolone & $0.55-1.25$ & $\begin{array}{l}\text { Stone et al. 1999; Eason et al. } \\
\text { 2002; Newton et al. } 1997\end{array}$ \\
\hline Laboratory rat & Rattus norvegicus & Bromadiolone & $0.56-0.84$ & $\begin{array}{l}\text { Erickson \& Urban } 2004 \\
\text { EU risk assessment }{ }^{1}\end{array}$ \\
\hline Mouse & Mus musculus & Bromadiolone & $0.99-1.75$ & $\begin{array}{l}\text { Stone et al. 1999; } \\
\text { Newton et al. } 1997\end{array}$ \\
\hline $\begin{array}{l}\text { Laboratory } \\
\text { mouse }\end{array}$ & Mus musculus & Bromadiolone & 1.75 & Erickson \& Urban 2004 \\
\hline Dog & $\begin{array}{l}\text { Canis lupus } \\
\text { familiaris }\end{array}$ & Bromadiolone & $8.1-15$ & $\begin{array}{l}\text { Stone et al. 1999; } \\
\text { Erickson \& Urban } 2004\end{array}$ \\
\hline Cat & Felis catus & Bromadiolone & $>25$ & $\begin{array}{l}\text { Stone et al. 1999; } \\
\text { Erickson \& Urban } 2004\end{array}$ \\
\hline Rat & Rattus norvegicus & Difenacoum & $0.29-1.8$ & $\begin{array}{l}\text { Eason et al. 2002; } \\
\text { Erickson \& Urban } 2004\end{array}$ \\
\hline Mouse & Mus musculus & Difenacoum & 0.47 & Erickson \& Urban 2004 \\
\hline Laboratory rat & Rattus norvegicus & Difenacoum & 0.55 & Erickson \& Urban 2004 \\
\hline $\begin{array}{l}\text { Laboratory } \\
\text { mouse }\end{array}$ & Mus musculus & Difenacoum & 1.29 & Erickson \& Urban 2004 \\
\hline Rat & Rattus norvegicus & Difenacoum & $1.8-2.6$ & EU risk assessment ${ }^{1}$ \\
\hline Pig & Sus domestica & Difenacoum & $2-3$ & Erickson \& Urban 2004 \\
\hline Dog & $\begin{array}{l}\text { Canis lupus } \\
\text { familiaris }\end{array}$ & Difenacoum & $4-11.8$ & Erickson \& Urban 2004 \\
\hline Cat & Felis catus & Difenacoum & $>16$ & Erickson \& Urban 2004 \\
\hline Rat & Rattus norvegicus & Difethialone & $0.4-0.8$ & EU risk assessment ${ }^{1}$ \\
\hline Dog & $\begin{array}{l}\text { Canis lupus } \\
\text { familiaris }\end{array}$ & Difethialone & 11.81 & EU risk assessment ${ }^{1}$ \\
\hline Rat & Rattus norvegicus & Flocoumafen & $0.13-0.5$ & EU risk assessment ${ }^{1}$ \\
\hline Rat & Rattus norvegicus & Flocoumafen & 0.25 & Eason et al. 2002 \\
\hline Mouse & Mus musculus & Flocoumafen & 1.13 & Newton et al. 1997 \\
\hline
\end{tabular}

${ }^{1}$ http://circa.europa.eu/Public/irc/env/bio_reports/library?!=/assessement_directive\&vm=detailed\&sb=Title

\subsection{Accumulation and elimination}

The greater potency of second generation anticoagulants compared to first generation anticoagulants is related to accumulation and slow elimination from the body after absorption. The anticoagulants accumulate in the liver which is the target organ for their action. Eason et al. (2002) present a following synthesis of the literature on the relative retention of anticoagulants in the liver after sub-lethal exposure: 
- low potency anticoagulants, warfarin and pindone: 0.5-1.0 month

- moderate potency anticoagulants, coumatetralyl, chlorophacinone and diphacinone: 3-6 months

- high potency anticoagulants, difenacoum, bromadiolone, flocoumafen, brodifacoum and difethialone: 6-12 months.

Pindone and diphacinone are not legal in the EU/EEA. A summary of body half-lives and retention times of some second generation anticoagulants in the livers of different animals are given in Table 3.

Brodifacoum has a very long body half-life (150-200 days). It is extremely persistent in liver and, to a lesser extent, in muscle tissue (Erickson \& Urban 2004; Eason et al. 1999). Elimination from liver is slow and biphasic with a very prolonged terminal phase. After administration of brodifacoum and bromadiolone to rats in a single oral dose of $0.2 \mathrm{mg} / \mathrm{kg}$ the half-lives in liver were 63 days for brodifacoum and 17 days for bromadiolone in the first elimination phase (28 days), and 282 and 318 days in the terminal phase, respectively. Mean liver concentrations of brodifacoum were significantly higher compared to bromadiolone throughout the study (Hawkins et al. 1991, in Erickson \& Urban 2004). In the study by Batten and Bratt (1987, in Erickson \& Urban 2004), 21 to 34\% of brodifacoum in livers of rats was still detected after 13 weeks from dosing, and more than $11 \%$ after 104 weeks. Rats also displayed signs of internal haemorrhage.

Murphy et al. (1998a) detected brodifacoum in the livers of 17 of 25 sampled rats at Waipapa, New Zealand. The proportion of rats which contained poison residues was $75 \%$ during the poison campaign. Three months after removal of baits still $61 \%$ of the rats captured contained poison residues. During the poisoning operation, the mean residue level of brodifacoum in poisoned rats was $0.87 \mathrm{mg} / \mathrm{kg}$. The mean concentration of brodifacoum in rats captured in the post-poisoning period was 0.17 $\mathrm{mg} / \mathrm{kg}$, and the last rat containing poison residue $(0.18 \mathrm{mg} / \mathrm{kg})$ was captured 13 weeks after all baits were removed from the bait stations.

Sub-lethal doses of brodifacoum can persist in the liver of sheep for over 16 weeks (Eason \& Spurr 1995). Bromadiolone was detected for 256 days in the liver of sheep that received a sub-lethal dose of $2 \mathrm{mg} / \mathrm{kg}$ (Erickson \& Urban 2004). Substantial amounts of brodifacoum were found in the livers of sub-lethally dosed possums (Trichosurus vulpecula) eight months after exposure, with little decline after the first week (Eason et al. 1996).

Bromadiolone persists very long in the liver, up to 270 days (Giraudoux et al. 2006). Erickson \& Urban (2004) have reported half-lives in the liver between 170-318 days. In livers of rats fed for 1 day with feed containing $50 \mathrm{mg} / \mathrm{kg}$ bromadiolone, concentrations were $2.08 \mathrm{mg} / \mathrm{g}$ after 1 day and $0.6 \mathrm{mg} / \mathrm{g}$ after 3 days. Even after a single oral exposure of 0.2 $\mathrm{mg} / \mathrm{kg}$ bromadiolone, liver concentrations of $0.3 \mathrm{mg} / \mathrm{g}$ were detected after 
200 days (Fournier-Chambrillon et al. 2004). In the study of Giraudoux et al. (2006), total residues in field voles (Microtus agrestis) exposed to baits containing $150 \mathrm{mg} / \mathrm{kg}$ bromadiolone reached $1.22 \mathrm{mg} / \mathrm{kg}$ on average and almost all of the animals caught had detectable bromadiolone residues in all tissues. Concentrations were at a maximum from 3.3 to 6.5 days after treatment for water voles (Arvicola terrestris), and after 1.33.7 days for common voles (Microtus arvalis). Predators may have access to a large proportion of contaminated voles, each of them containing on average $93.5 \mu \mathrm{g}$ (including guts) or $57.6 \mu \mathrm{g}$ (without guts) of bromadiolone. After 135 days, eight out of the ten water voles and one of the two common voles still had detectable residues. This indicates that although the risk of secondary poisoning is at a maximum during the first 15-20 days of the control campaign when the rodent densities remain high, exposure conditions are maintained at least for 135 days.

The half-life of flocoumafen in the liver is estimated to be between 100 and 220 days (Huckle et al. 1989; Newton et al. 1994). Sub-lethal doses of flocoumafen can accumulate and persist in rats for 14 weeks (Eason \& Spurr 1995).

Many rat and mice populations have developed resistance against the first generation anticoagulants. This was also the reason for the introduction of the second generation substances. Resistance against the second generation anticoagulants is not very common, but is observed in some areas. Resistant rodents are assumed to pose a greater risk to predators than susceptible rats because they have higher body burdens and are expected to be available for predation for a longer time compared to nonresistant rats, which die faster (Atterby et al. 2005). Atterby et al. (2005) described a feeding test with difenacoum at $25 \mathrm{mg} / \mathrm{kg}$ for 5,10 , or 20 days in anticoagulant-resistant or susceptible rats. Whole-carcass difenacoum residues reached values around $0.6 \mathrm{mg} / \mathrm{kg}$, resistant rats having higher residues than the susceptible ones $(0.679 \mathrm{mg} / \mathrm{kg}$ compared to $0.519 \mathrm{mg} / \mathrm{kg}$ after five days). 
Table 3. Half-lives and elimination times of anticoagulants in the livers of target and non-target animals.

\begin{tabular}{|c|c|c|c|c|c|c|}
\hline $\begin{array}{l}\text { Common } \\
\text { name }\end{array}$ & $\begin{array}{l}\text { Scientific } \\
\text { name }\end{array}$ & Anticoagulant & $\begin{array}{l}\text { Dose } \\
\mathrm{mg} / \mathrm{kg}\end{array}$ & $\begin{array}{r}\text { Elimina- } \\
\text { tion time, } \\
\text { days }\end{array}$ & $t^{1 / 2}$ days & Reference \\
\hline Rat & $\begin{array}{l}\text { Rattus } \\
\text { norvegicus }\end{array}$ & Brodifacoum & 0.35 & & 130 & $\begin{array}{l}\text { Erickson \& Urban } \\
2004\end{array}$ \\
\hline Rat & $\begin{array}{l}\text { Rattus } \\
\text { norvegicus }\end{array}$ & Brodifacoum & 0.25 & & $150-200$ & $\begin{array}{l}\text { Erickson \& Urban } \\
2004\end{array}$ \\
\hline Rat & $\begin{array}{l}\text { Rattus } \\
\text { norvegicus }\end{array}$ & Brodifacoum & 0.2 & & $282-350$ & $\begin{array}{l}\text { Erickson \& Urban } \\
2004, \\
\text { EU risk assessment }{ }^{1}\end{array}$ \\
\hline Rat & $\begin{array}{l}\text { Rattus } \\
\text { norvegicus }\end{array}$ & Bromadiolone & 0.93 & & 170 & $\begin{array}{l}\text { Erickson \& Urban } \\
2004\end{array}$ \\
\hline Rat & $\begin{array}{l}\text { Rattus } \\
\text { norvegicus }\end{array}$ & Bromadiolone & 0.2 & & 318 & $\begin{array}{l}\text { Erickson \& Urban } \\
2004, \\
\text { EU risk assessment }{ }^{1}\end{array}$ \\
\hline Rat & $\begin{array}{l}\text { Rattus } \\
\text { norvegicus }\end{array}$ & Difenacoum & & & $108-120$ & Eason et al. 2002 \\
\hline Rat & $\begin{array}{l}\text { Rattus } \\
\text { norvegicus }\end{array}$ & Difenacoum & & & 118 & EU risk assessment ${ }^{1}$ \\
\hline Rat & $\begin{array}{l}\text { Rattus } \\
\text { norvegicus }\end{array}$ & Difethialone & 0.5 & & 126 & $\begin{array}{l}\text { Erickson \& Urban } \\
2004, \\
\text { EU risk assessment }{ }^{1}\end{array}$ \\
\hline Rat & $\begin{array}{l}\text { Rattus } \\
\text { norvegicus }\end{array}$ & Flocoumafen & & & 215 & EU risk assessment ${ }^{1}$ \\
\hline Rat & $\begin{array}{l}\text { Rattus } \\
\text { norvegicus }\end{array}$ & Flocoumafen & & & 220 & Eason et al. 2002 \\
\hline Barn owl & Tyto alba & Flocoumafen & & $>100$ & & Eason et al. 2002 \\
\hline Dog & $\begin{array}{l}\text { Canis lupus } \\
\text { familiaris }\end{array}$ & Flocoumafen & & $>300$ & & Eason et al. 2002 \\
\hline
\end{tabular}

${ }^{1}$ http://circa.europa.eu/Public/irc/env/bio_reports/library?l=/assessement_directive\&vm=detailed\&sb=Title

Giraudoux et al. (2006) calculated daily intakes of bromadiolone for different animal species feeding on water voles (Arvicola terrestris), assuming that voles contain on average $93.5 \mathrm{mg}$ (including guts) or $57.6 \mathrm{mg}$ (without guts) of bromadiolone, as mentioned above. Adult red foxes (Vulpes vulpes) eat between 0.3 and $0.6 \mathrm{~kg}$ of food daily. This means that if they feed on water voles exclusively (which is realistic during highdensity peaks) they may eat between four and eight individual voles and thus ingest 364-728 mg of bromadiolone per day on average. This corresponds to a daily acute dose of 60-121 mg of bromadiolone/kg bw/day.

Stoats (Mustela erminea) usually discard the digestive tract, but not the liver, when they feed on small mammals. Stoats weigh 180-330 grams (depending on sex), and their daily intake ranges between 0.37 and $0.62 \mathrm{~g} / \mathrm{g}$. This means that the food consumption may range between 67 and $204 \mathrm{~g} /$ day, which corresponds to between one and more than three individual water voles/day. Thus, the bromadiolone daily intake would range between 58-173 $\mathrm{mg}$. A minimum value of bromadiolone (58 mg) could lead to an acute dose of $174-320 \mathrm{mg} / \mathrm{kg}$, according to stoat body weights.

Common buzzards (Buteo buteo) weigh between 0.5-1.35 kg depending on the sex. Daily food intake varies between 40-170 grams, pointing to an average intake ranging between 48.8 and $207.4 \mathrm{mg}$ of bromadiolone. The average minimum dose (large animals eating a low vole num- 
ber) would reach $36 \mathrm{mg} / \mathrm{kg}$ but may be closer to $153 \mathrm{mg} / \mathrm{kg}$. No data on LD50 are available on birds of prey for bromadiolone, but a daily dose of $279 \mathrm{mg} / \mathrm{kg} /$ day of difenacoum has been shown sufficient to kill a barn owl (Tyto alba, Gray et al. 1994).

Eason and Murphy (2001) emphasize that the risk of anticoagulant rodenticides is magnified by their persistence, which could lead to accumulation in cases of repeated exposure. A compound that is rapidly metabolized or excreted from a primary consumer may result in a lesser risk than one that bioaccumulates with repeated sub-lethal exposure, even if repeated exposure occurs weeks or even months after the initial exposure.

\subsection{Secondary exposure of non-target species}

\subsubsection{Laboratory studies on secondary poisoning}

The target rodents form a variable proportion of the diet of many predatory and scavenging species such as the weasel (Mustela nivalis), barn owl (Tyto alba), long-eared owl (Asio otus), short-eared owl (Asio flammeus) and tawny owl (Strix aluco). Generalists, such as the red fox, polecat (Mustela putorius), buzzard and red kite (Milvus milvus), rely less on small mammals and change their feeding habits depending on available prey (Shore et al. 1999; Berny et al. 2007). Kestrels, stoats and weasels are specialist predators of non-target small mammals, e.g. woodmouse (Apodemus sylvaticus), bank vole (Clethrionomys glareolus) and field vole (Microtus agrestis), which have shown to feed on rodenticide from bait boxes during rat control campaigns (Brakes \& Smith 2005).

Anticoagulants are toxic to all vertebrates. Invertebrates are less susceptible as their blood clotting systems differ from that of vertebrates (Shirer 1992, in Eason \& Spurr 1995), but it has been suggested that invertebrates have a potential to carry poison to vertebrates (Stephenson et al. 1999, in Eason et al. 2002). The potential exposure routes could be the consumption of rodent faeces, the consumption of rodent carcasses, ingestion of soilbound residues by e.g. earthworms, and direct consumption of poison baits (Dowding et al. 2010). Shrews are insectivores and are not expected to feed on grain-based bait, yet several shrews were found dead with dyed faeces in traps (Brakes \& Smith 2005). (Baits are dyed as birds are assumed to avoid coloured baits (Moran 2001) and dyes can also reveal anticoagulant poisoning of non-target animals.) Residues of bait have been found in shrews, indicating that shrews may have eaten grain bait opportunistically or they may have consumed contaminated invertebrates or carrion. Also insectivorous birds have been found dead after eating ants and cockroaches that have fed on brodifacoum baits (Brakes \& Smith 2005). Dowding et al. (2010) have recently shown that $66.7 \%$ of 120 analysed 
individuals of the European hedgehog (Erinaceus europaeus) contained residues of first and second generation anticoagulants.

Mendenhall and Pank (1980) compared secondary hazards of 3 second generation and 3 first generation anticoagulants to barn owls. Six owls (per rodenticide) were exposed to rats fed with brodifacoum (20 ppm bait), bromadiolone (50 ppm bait) or difenacoum (50 ppm bait) and two owls (per rodenticide) were exposed to rats fed with diphacinone (50 ppm bait), chlorophacinone (50 ppm bait) or fumarin (250 ppm bait). Six of the 18 owls (33\%) exposed to second generation anticoagulants died, whereas none of the 6 owls offered first-generation anticoagulantpoisoned rats exhibited any signs of intoxication. Brodifacoum-fed rats accounted for 5 of the 6 owl deaths. The other mortality occurred in 1 of 2 owls exposed to bromadiolone-fed rats for 10 days. Sub-lethal haemorrhage occurred in owls fed difenacoum-fed rats.

Newton et al. (1990) gave mice feed containing 20 ppm brodifacoum or difenacoum. The mice died after 2-11 days, and mean residues in the whole carcasses (35 g) were $10.17 \mu \mathrm{g}$ for difenacoum and $15.36 \mu \mathrm{g}$ for brodifacoum. Six barn owls fed with difenacoum-poisoned mice survived after consuming $101.7 \mu \mathrm{g}$ of difenacoum (on average) and their blood coagulation time returned to near normal in 5-23 days. Of six barn owls fed with brodifacoum-dosed mice, four died 6-7 days after the treatment. In average, the amount of brodifacoum in these owls was $46.07 \mu \mathrm{g}(0.15-$ $0.182 \mathrm{mg} / \mathrm{kg}$ ) and the liver residues ranged from 0.63 to $1.25 \mathrm{mg} / \mathrm{kg}$.

\subsubsection{Factors influencing primary and secondary exposure}

In the risk assessment of anticoagulant rodenticides, primary and secondary poisoning has been identified as a major concern for the environment. Exposure calculations according to the emission scenario for rodenticides show that feeding on the poisoned target rodent results in secondary poisoning (Larsen 2003). In nature, accumulation of anticoagulants to birds and mammals from non-target rodents may be an even more important exposure route. It has been noticed that non-target rodents feed on baits even during a properly performed control campaign. Findings of residues in birds which seldom prey on target rodents also support the observation that there is accumulation via non-target rodents. In general, voles are the preferred food of many raptorial bird species and target rodents form only a minor proportion of the raptors' diet under normal conditions.

The following factors have been noticed to influence the exposure of non-target animals:

- the wildlife species found in and around treatment areas, since the composition of the species community contributes to the main prey 
species of predators in a certain area, and thereby to the risk of secondary poisoning

- the species' food habits and foraging behaviour, e.g. if a predator is a specialist or generalist, and whether it eats the whole carcass or only parts of it, et cetera.

- home range, some predators may live in a wide area and therefore prey on animals from several treatment areas

- propensity to feed in and near human buildings, since these are the main focus areas of poisoning

- bait availability (e.g., quantity, and how, where and when applied), since there is a clear correlation between the amount of baits, duration of poisoning operations, and exposure of non-target animals

Primary and secondary poisoning of non-target animals can be reduced by various measures. Use of anticoagulants could be restricted to in and around buildings or to indoor use only. Specific product design can make baits less accessible, in particular to birds and domestic animals, and can thus reduce the exposure. For example, the inclusion of a blue dye is believed to render the product unattractive to birds, and non-dusting formulations prevent the rodenticide from spreading to the environment. Bait boxes may be useful to prevent access by other than target animals, and baits should also be secured so that they cannot be dragged away. Unfortunately, bait boxes do not prevent non-target animals which are smaller than or of equal size to the target rodents from getting to the bait. Searching for and removing dead rodents during treatment is also recommended, at least as often as baits are checked and/or replenished. Disposing of dead rodents in accordance with local environmental requirements could also reduce the risk of secondary poisoning. However, this may not be a very effective measure as only a small proportion of the controlled rodent population is found dead during or after the control campaign. After treatment all remaining baits should be removed and disposed of

(http://ec.europa.eu/environment /biocides/pdf/anticoagulants.pdf Ref. 1.10.2009).

Despite these actions, there is no doubt that many birds and non-target mammals are attracted to, and will consume grain-based foods. These exposed non-target animals are then eaten up by predators and scavengers. Poisoned rodents may also leave trails of blood, stray away from cover and have slower reactions than unpoisoned ones, making them more vulnerable to predation (Murphy et al. 1998b). Up to 73\% of dead poisoned muskrats (Ondatra zibethicus) were detected above ground, increasing the risk of secondary poisoning (Tuyttens \& Stuyck 2002). According to Sage et al. (2008) storing of baits by water voles increases the persistence of bromadiolone even up to 10 times. This could also lead to a delayed exposure of rodent predators during a possible recolonization by voles. Determining the relationship between an exposure 
and the resulting dose in target tissue is therefore a critical issue encountered in quantitative risk assessment, since the mechanism of anticoagulant metabolism and excretion is poorly known. While primary exposure of larger non-target animals may be reduced by the use of bait stations, secondary exposure is more difficult to manage due to the prolonged effect of the anticoagulant (Eason et al. 2002).

Predators and scavengers are not expected to only consume contaminated animals, and therefore the estimation of degree of exposure is difficult. The risk of secondary poisoning of avian predators and scavengers from anticoagulant-poisoned prey is related to exposure factors such as the behaviour of the target species during the latent (pre-mortality) period, the location of carcasses (above or below ground), the anticoagulant residue loading in the target species, as well as the behaviour and diet of the non-target species (Howald et al. 1999). Newton et al. (1990) note that there remains the possibility that sub-lethal levels of rodenticides may predispose to death from other causes, or reduce the chance of recovery from accidents. The relationship between usage patterns and occurrence of liver residues in predators is also complex and potentially affected by physiological, ecological and anthropomorphic factors (Shore et al. 2003, 2006 in Walker et al. 2008a). 



\section{Review on studies on anticoagulant secondary poisoning in wildlife}

\subsection{United Kingdom}

Secondary poisoning of mustelids and raptors by anticoagulant residues in Britain has been demonstrated by e.g. Barnett et al. 2003, 2004; Newton et al. 1990; Shore et al. 1996, 2003; McDonald et al. 1998 and Walker et al. 2008a. Anticoagulant residues have been found in e.g. barn owl, buzzard, red kite, crow, fox, kestrel and polecat. More than 30\% of studied barn owls and polecats contained difenacoum residues (Newton et al. 1997; Shore 2003). In general, the residue levels are low and are not considered to be the primary cause of death. We have not found studies where effects of sublethal residue levels have been examined. However, in some incidents the animals have been determined to having died of haemorrhages.

In the UK the Wildlife Incident Investigation Scheme (WIIS) investigates deaths of wildlife where there is evidence to suggest that pesticide poisoning may be involved. Most sampling is done by the public, who find casualties and suspect that pesticides may have played a role in harming them. The carcasses are examined and chemical analyses are done on tissues. The pesticide incidents are assigned to one of four categories: approved use, misuse, abuse (deliberate poisoning attempts) and unspecified use where the cause could not be assigned to one of the above categories. Exposure of non-target animals to anticoagulant rodenticides is likely more widespread than the number of incidents suggests. Due to delayed effect and the living habits of predators the carcasses may usually not be detected (Birks et al. 1998). It is also noteworthy that small mammals like mice and voles are underrepresented in these incidents, since people do not deliver these animals for analyses. Either they are not discovered when dead or the carcasses are ignored.

The suspected secondary poisoning incidents, belonging to classes of approved use or unspecified use and involving birds of prey or carnivorous mammals (cats and dogs excluded) are summarized in table 4. According to WIIS data from 2004, rodenticide residues were found in every third of the buzzards investigated. The residue concentrations have not been given in the reports, and therefore only the concerned substance and species are given. 
Table 4. Number of non-target species with brodifacoum, bromadiolone or difenacoum residues in the UK in 1998-2006. In addition there was one incident where flocoumafen was found in tawny owl. From Barnett et al. 1999-2007 (WIIS data).

\begin{tabular}{|c|c|c|c|c|}
\hline \multirow[t]{2}{*}{ Common name } & \multirow[t]{2}{*}{ Scientific name } & \multicolumn{3}{|c|}{ Number of incidents 1998-2006 } \\
\hline & & Bromadiolone & Difenacoum & Brodifacoum \\
\hline Buzzard & Buteo buteo & 30 & 42 & 2 \\
\hline Red kite & Milvus milvus & 32 & 41 & 7 \\
\hline Fox & Vulpes vulpes & 32 & 6 & 4 \\
\hline Barn owl & Tyto alba & 11 & 9 & 3 \\
\hline Sparrow hawk & Accipiter nisus & 5 & 5 & 0 \\
\hline Tawny owl & Strix aluco & 3 & 5 & 3 \\
\hline Badger & Meles meles & 4 & 4 & 1 \\
\hline Kestrel & Falco tinnunculus & 3 & 3 & 0 \\
\hline Otter & Lutra lutra & 3 & 2 & 0 \\
\hline Peregrine falcon & Falco peregrinus & 1 & 0 & 1 \\
\hline Eagle owl & Bubo bubo & 0 & 1 & 0 \\
\hline Golden eagle & Aquila chrysaetos & 1 & 0 & 0 \\
\hline Marsh harrier & Circus aeruginosus & 0 & 2 & 0 \\
\hline Stoat & Mustela erminea & 1 & 0 & 0 \\
\hline
\end{tabular}

Use of rodenticides on farms is widespread in the UK. In 2000, 91\% of farms used rodenticides (McDonald \& Harris 2000). Difenacoum is reported to be the most widely used rodenticide on arable farms and game estates. Surveys of rodenticide contamination in kestrel (Shore et al. 2003), stoat and weasel (McDonald et al. 1998) have all demonstrated significant rodenticide residues. Because of their heavy predation on rodents, mustelids may be at high risk for secondary poisoning by anticoagulant rodenticides, like several birds of prey such as barn owls and red kites (Shore et al. 2003).

Shawyer (1987, in Newton et al. 1990) reported suspected poisonings in barn owls associated with the use of brodifacoum (four cases), difenacoum (four cases) and bromadiolone (one case) between 1982 and 1985. Subsequently, about $10 \%$ of 145 barn owls found dead in Britain between 1983 and 1989 were found to contain detectable (>0.005 ppm) levels of brodifacoum. In the study by Walker et al. (2008), 33 (19.2\%) of the 172 tawny owl livers analysed contained detectable concentrations of one or more rodenticides. The occurrence of individual rodenticides was $11.6 \%$, $5.8 \%$, and $4.7 \%$ for bromadiolone, difenacoum, and brodifacoum, respectively. Tawny owl carcasses were collected through the Predatory Bird Monitoring Scheme, a long-term UK chemical monitoring program.

Newton et al. (1997) reviewed the mortality causes in British barn owls. Of 557 birds examined during 1983-1994, 132 (24\%) contained residues of rodenticides, either difenacoum, brodifacoum, bromadiolone, flocoumafen or more than one of these compound (Table 5). 10\% of 145 barn owls found dead in the period 1983-1989 contained residues of difenacoum $(0.005-0.106 \mathrm{mg} / \mathrm{kg} \mathrm{bw})$ or brodifacoum (0.019-0.515 $\mathrm{mg} / \mathrm{kg}$ bw) (Newton et al., 1990). The proportion of birds in which residues were detected increased over the years, reaching 32\% in 1993-1994. Eight birds were concluded to having died of rodenticide poisoning (Table 6), meaning that no other cause of death was found. Except for in 
these eight birds, the residues were considered to be at sub-lethal level, and most deaths resulted directly from collisions with cars and trucks or starvation. However, the proportion of deaths due to rodenticides may have been underestimated, since death from anticoagulant exposure is delayed and preceded by lethargy, and most victims are likely to die in their roosts where they are not likely to be found. According to Newton et al. (2003), barn owls appear to be one of the most susceptible species to rodenticides.

Table 5. Percentage of barn owls with anticoagulant residues in the UK (Newton et al. 1997).

\begin{tabular}{lcr}
\hline Period & Number with residues/ Number of owls analyzed & Percent containing residues \\
\hline $1983-1984$ & $1 / 18$ & 6 \\
$1985-1986$ & $9 / 75$ & 12 \\
$1987-1988$ & $8 / 61$ & 13 \\
$1989-1990$ & $31 / 133$ & 23 \\
$1991-1992$ & $41 / 139$ & 29 \\
$1993-1994$ & $42 / 131$ & 32 \\
\hline
\end{tabular}

Table 6. Concentrations of residues in barn owls that were diagnosed as having died to anticoagulant poisoning in the UK between 1983 and 1994. (Newton et al. 1997)

\begin{tabular}{llr}
\hline Specimen number & Compound & Concentration $\mathbf{~ m g / k g}$ \\
\hline 1 & Bromadiolone & 0.13 \\
2 & Bromadiolone & 0.05 \\
& Flocoumafen & 0.003 \\
& Brodifacoum & 0.02 \\
3 & Difenacoum & 0.17 \\
4 & Bromadiolone & 1.07 \\
5 & Brodifacoum & 0.87 \\
6 & Bromadiolone & 1.72 \\
& Brodifacoum & 0.07 \\
7 & Bromadiolone & 0.33 \\
8 & Brodifacoum & 0.42 \\
\hline
\end{tabular}

McDonald et al. (1998) detected anticoagulant rodenticides in 23\% (9 of 40) of stoats and $30 \%$ (3 of 10) of weasels received from gamekeepers in the UK between August 1996 and March 1997. The most frequently found substance was coumatetralyl which was found in six stoats and three weasels in concentrations ranging from 0.0046 to $0.06 \mathrm{mg} / \mathrm{kg}$. Bromadiolone was found in three stoats in concentrations of $0.04-0.38$ $\mathrm{mg} / \mathrm{kg}$ and one weasel $(0.25 \mathrm{mg} / \mathrm{kg})$. Brodifacoum was found in one stoat $(0.12 \mathrm{mg} / \mathrm{kg})$.

A dataset of 100 polecats collected throughout the 1990's from across the whole of their prevailing range was created by combining three different studies. Shore et al. (1996) analyzed livers of 24 road-killed polecats and found anticoagulant rodenticides in $31 \%$ of the animals. A second study by Shore et al. (1999), in which the livers of another 26 adult animals were analyzed for the same compounds, was carried out in 1999. In 2003, Shore et al. reported measurements of rodenticide concentrations in the livers of 50 polecats. At least one rodenticide was detected in the 
livers of 13 out of 37 (35.1\%) male and 5 out of 13 (38.5\%) female polecats (Shore et al. 2003).

Overall, 31\% of the analysed polecats contained residues (Table 7). Bromadiolone (0.034-0.217 $\mathrm{mg} / \mathrm{kg})$ and difenacoum (0.005-0.917 $\mathrm{mg} / \mathrm{kg}$ ) were found most frequently. Brodifacoum was found in three animals. Flocoumafen was not detected, probably because it is not commonly used in Great-Britain. Results indicate that exposure of polecats to second generation rodenticides may be common, as a matter of fact around a third of adult polecats are exposed to second generation rodenticides in the western England. Shore et al. (2003) also note that it is possible that this may even be an underestimate because analysis of road-kills may involve a bias against detection of pesticide residues and animals in which no residues were detected may have eliminated any earlier contamination. However, the frequency with which residues were detected in polecats was very similar to that in barn owls, another rodent predator about which there has been concern over secondary exposure to second generation rodenticides.

Table 7. Residues of anticoagulant rodenticides in polecats in the UK (Shore et al. 1996, 1999 \& 2003).

\begin{tabular}{lllr}
\hline \multirow{2}{*}{$\begin{array}{l}\text { Year (Number of } \\
\text { animals) }\end{array}$} & \multicolumn{3}{c}{ Average residues (range) $\mathbf{m g} / \mathbf{k g}$} \\
\cline { 2 - 4 } & Difenacoum & Bromadiolone & Brodifacoum \\
\hline $1993(5)$ & $0.319(0.016-0.581)$ & - & 0.07 \\
$1994(7)$ & $0.13(0.005-0.321)$ & $0.125(0.039-0.217)$ & 0.008 \\
$1995(1)$ & - & 0.095 & - \\
$1996(2)$ & 0.016 & 0.016 & - \\
$1997(7)$ & $0.182(0.019-0.319)$ & $0.074(0.018-0.095)$ & - \\
$1998(7)$ & $0.179(0.03-0.397)$ & $0.064(0.034-0.094)$ & 0.052 \\
$1999(2)$ & $0.649(0.381-0.917)$ & 0.186 & - \\
\hline
\end{tabular}

During the period 1998-2001 14 red kites died due to anticoagulant rodenticide poisoning and one or more residues of brodifacoum, bromadiolone and difenacoum were detected in the carcasses (Barnett et al. 20002002). In 1994-2005, exposure to anticoagulant rodenticides was widespread among kites, since $73.9 \%$ of birds analyzed had detectable residues in their livers (Table 8). Two or three different rodenticides were found in the livers of almost half of the birds (Walker et al. 2008b). This suggests that multiple exposure events are relatively common.

Table 8. The occurrence and concentrations of second generation anticoagulant rodenticides in the livers of 23 red kites found dead in the UK between 1994 and 2005 (Walker et al. 2008b).

\begin{tabular}{lll}
\hline Substance & No of birds with detectable residues & Mean liver concentration (range) \\
\hline Difenacoum & $11(47.8 \%)$ & $0.052(0.04-0.067)$ \\
Bromadiolone & $12(52.2 \%)$ & $0.073(0.056-0.094)$ \\
Flocoumafen & $1(4.3 \%)$ & 0.015 \\
Brodifacoum & $7(30.4 \%)$ & $0.125(0.071-0.222)$ \\
$\geq$ One substance & $17(73.9 \%)$ & $0.166(0.137-0.2)$ \\
Two substances & $6(26.1 \%)$ & \\
Three substances & $4(17.4 \%)$ & \\
\hline
\end{tabular}




\subsection{France}

Berny et al. (1997, 2007, 2008), Lambert et al. (2007) and FournierChambrillon et al. (2004) have investigated rodenticide poisonings in France and found that secondary poisoning is highly common, due to abundant use of rodenticides.

According to Berny et al. (1997), anticoagulant poisoning is among the most common causes of poisoning in domestic and wild animals in France. They present the result of a 4 year survey in France based on the activity of a wildlife disease surveillance network (SAGIR). Foxes, buzzards, one heron (Ardea cinerea) and one stoat were found dead with signs of internal haemorrhages in the vicinity of rodenticide-treated areas. All these species are carnivorous and potential consumers of field voles. Bromadiolone was detected in the livers of 22 of 31 red foxes, 15 of 16 buzzards, 5 of 5 kites, 2 of 13 rabbits (Oryctolagus cuniculus), 2 of 14 hares (Lepus capensis), 3 of 6 wild boars (Sus scrofa), 2 of 2 roe deers (Capreolus capreolus) and 2 of 2 stone martens (Martes foina). In addition, bromadiolone was found in one lynx (Lynx lynx), badger (Meles meles), harrier (Circus pygargus), mallard (Anas platyrhynchos), swan (Cygnus sp.) and heron (Ardea cinerea). Based on the species involved, secondary poisoning seems to have been the predominant route of exposure. Liver concentrations in the most commonly exposed foxes were 1.5 $\mathrm{mg} / \mathrm{kg}$ and in buzzards $0.4 \mathrm{mg} / \mathrm{kg}$.

Fournier-Chambrillon et al. (2004) estimated the exposure of 122 dead riparian mustelids of four species, European mink (Mustela lutreola), American mink (M. vison), polecat (M. putorius) and European otter (Lutra lutra) collected between 1990 and 2002 in south western France: bromadiolone was found in all species and in $9 \%$ of the collected carcasses (one of 31 European mink, three of 47 American mink, five of 33 polecats, and two of 11 European otters). Liver concentrations ranged from $0.6 \mathrm{mg} / \mathrm{kg}$ to $9.0 \mathrm{mg} / \mathrm{kg}$. Chlorophacinone was found in two species and in $4 \%$ of the collected carcasses, with liver concentrations ranging from $3.4 \mathrm{mg} / \mathrm{kg}$ to $8.5 \mathrm{mg} / \mathrm{kg}$. Two polecats and one American mink had lesions and liver residues indicating that bromadiolone was directly responsible for their deaths.

Anticoagulant rodenticides were detected or quantified in the liver of 22 of 30 raptors (73\%) and 4 of 28 water birds (14\%) (Lambert et al 2007). Bromadiolone was detected in the liver of 15 birds, difenacoum in the liver of 8 birds and brodifacoum in the liver of 4 birds. The most contaminated bird species was buzzard. Saucy et al. (2001) also reported deaths of numerous birds, mostly Eurasian buzzards but also kites and carrion crows, 38 wild mammals, mostly red foxes and mustelids, and 18 cats and dogs, after bromadiolone bait (150 ppm) was mechanically applied in underground burrows for water vole control in Switzerland. 
Over the period 1992-2002, 62 red kites were found dead and poisoning was the confirmed cause of death in over $80 \%$ of these cases (Berny \& Gaillet 2008). The major toxicants were anticoagulant rodenticides used to control water vole populations.

\subsection{United States}

According to Erickson and Urban (2004), brodifacoum and difethialone stand out as the two rodenticides posing the greatest potential overall risk to birds and non-target mammals in the USA, followed by bromadiolone and diphacinone. The avian species most commonly exposed to anticoagulant rodenticides in the USA are great horned owls (Bubo virginianus) and red-tailed hawks (Buteo jamaicensis). Multiple poisoning incidents have also been reported for golden and bald eagles (Aquila chrysactos, Haliaeetus leucocephalus), corvids (Corvus spp.), barn owl, eastern screech owl (Otus asio), northern spotted owl (Strix occidentalis), Cooper's hawk (Accipiter cooperi), red-shouldered hawk (Buteo lieatus), sharp-shinned hawk (Accipiter striatus), peregrine falcon (Falco peregrinus), American kestrel (Falco sparverius), and vultures (Cathartes aura, Coragyps atratus). Carnivores for which incidents have been reported include coyotes, foxes, raccoons, bobcats, skunks, mountain lions and a weasel. Difenacoum and flocoumafen were not included in the risk assessment. The reason might be that these substances were not on the market on that time in the US.

The data used in the risk assessment of rodenticides made by the US EPA (Erickson and Urban 2004) consists of more than 300 incidents in which one or more rodenticides were detected in birds or non-target mammals. Brodifacoum was detected in more than 244 of incidents and bromadiolone in 39 incidents (Table 9). Brodifacoum residues have been detected in liver tissue of 27 of 32 endangered kit foxes screened for rodenticide residues between 1999 and 2003. Birds in which rodenticides are most frequently detected include owls, hawks, eagles, and corvids; mammals include wild canids and felids, tree squirrels, raccoons and others. Traces of difethialone were detected in one bobcat. In 11 secondary hazard studies where 149 raptors or scavengers were exposed to brodifacoum-poisoned prey, $42 \%$ of exposed birds died. Many survivors had signs of intoxication, including haemorrhage (Erickson \& Urban 2004). 
Table 9. Liver residues of brodifacoum and bromadiolone in avian and mammalian predators and scavengers in the US. The number of animals with residues is given in parenthesis after the range (Erickson \& Urban 2004).

\begin{tabular}{|c|c|c|c|}
\hline \multirow[t]{2}{*}{ Common name } & \multirow[t]{2}{*}{ Scientific name } & \multicolumn{2}{|c|}{ Liver residues ppm } \\
\hline & & Bromadiolone (n) & Brodifacoum (n) \\
\hline Great horned owl & Bubo virginianus & $0.065-0.8(9)$ & $0.01-0.84(41)$ \\
\hline Long-eared owl & Asio otus & - & $0.30(1)$ \\
\hline Eastern screech owl & Otus asio & $0.05-4.29(2)$ & $0.16-0.91(7)$ \\
\hline Northern saw-whet owl & Aegolius acadicus & $0.43(1)$ & - \\
\hline Barn owl & Tyto alba & $0.31-0.38(3)$ & $0.03-0.85(7)$ \\
\hline Barred owl & Strix varia & - & $0.04(1)$ \\
\hline Northern spotted owl & Strix occidentalis & - & $0.05-0.1(2)$ \\
\hline Golden eagle & Aquila chrysaetos & - & $0.03-0.85(13)$ \\
\hline Bald eagle & Haliaeetus leucocephalus & - & Detected (2) \\
\hline Red-tailed hawk & Buteo jamaicensis & $0.08(1)$ & $0.003-1.6(43)$ \\
\hline Red-shouldered hawk & Buteo lineatus & $0.28(1)$ & $0.01-0.23(3)$ \\
\hline Cooper's hawk & Accipiter cooperii & $0.24-0.6(2)$ & $0.03-0.37(6)$ \\
\hline Sharp-shinned hawk & Accipiter striatus & - & $0.023-0.17(2)$ \\
\hline Black vulture & Coragyps atratus & - & $0.13(1)$ \\
\hline Turkey vulture & Cathartes aura & - & $0.26(1)$ \\
\hline Raven & Corvus corax & - & $1.04(1)$ \\
\hline American crow & Corvus brachyrhynchos & - & $0.07-1.9(13)$ \\
\hline Fish crow & Corvus ossifragus & $2.1(1)$ & - \\
\hline Crow & Corvus corone & - & $0.14-1.67(4)$ \\
\hline Coyote & Canis latrans & $0.07-0.46(5)$ & $0.03-0.66(21)$ \\
\hline San Joaquin kit fox & Vulpes macrotis mutica & $0.14-0.72(2)$ & $0.007-11.0(27)$ \\
\hline Red fox & Vulpes vulpes & - & $0.04-4.01(5)$ \\
\hline Grey fox & Urocyon cinereoargenteus & - & $0.02-0.35(3)$ \\
\hline Bobcat & Felis rufus & $0.11(1)$ & $0.018-0.07(4)$ \\
\hline Mountain lion & Puma concolor & - & $0.52(1)$ \\
\hline Raccoon & Procyon lotor & $0.41-1.1(2)$ & $0.011-5.3(9)$ \\
\hline Long-tailed weasel & Mustela frenata & - & $0.07(1)$ \\
\hline Striped skunk & Mephitis mephitis & $0.08-0.29(3)$ & $0.3-1.05(2)$ \\
\hline
\end{tabular}

From 1971 to 1997, Stone et al. (1999) documented 51 cases of poisoning of non-target wildlife in New York State with anticoagulant rodenticides (Table 10). Brodifacoum was detected in $80 \%$ (41) of the incidents and bromadiolone in three cases (once in combination with brodifacoum). The most commonly poisoned species were great horned owl (13 cases) and red-tailed hawk (7 cases). For the period 1998-2001, anticoagulant rodenticides were detected in $49 \%$ of the 265 raptors analyzed in New York State. Brodifacoum was detected in $84 \%$ of the positive cases and bromadiolone in $22 \%$. Brodifacoum and bromadiolone were found in combination in 15 birds. Great horned owl was again the most frequently poisoned species. Among positive cases, brodifacoum levels were on average $0.18 \mathrm{mg} / \mathrm{kg}$ (range $0.005-1.28 \mathrm{mg} / \mathrm{kg}$ ) and bromadiolone levels on average $0.31 \mathrm{mg} / \mathrm{kg}$ (range $0.03-1.08 \mathrm{mg} / \mathrm{kg}$ ). Anticoagulants were detected in great horned owls (81\%), red-tailed hawks (58\%), Cooper's hawks (36\%), and screech owls (45\%) (Table 11). Based on lethal blood loss in the absence of severe injury or other factors, anticoagulantfacilitated haemorrhage was considered the cause of death in 28 cases (Stone et al. 2003). 
Table 10. Anticoagulant poisonings in wildlife in New York and adjoining states in the period 1989-1997 (Stone et al. 1999). Only poisonings caused by the second generation anticoagulants are reported here.

\begin{tabular}{|c|c|c|c|c|}
\hline \multirow[t]{2}{*}{ Common name } & \multirow[t]{2}{*}{ Scientific name } & \multirow[t]{2}{*}{ No. of animals } & \multicolumn{2}{|c|}{ Liver residues $\mathrm{mg} / \mathrm{kg}$} \\
\hline & & & Brodifacoum & Bromadiolone \\
\hline Common crow & Corvus corone & 1 & 1.34 & \\
\hline Eastern chipmunk & Tamias striatus & 1 & 3.8 & \\
\hline Golden eagle & Aquila chrysaetos & 1 & 1.04 & \\
\hline Gray squirrel & $\begin{array}{l}\text { Sciurus carolin- } \\
\text { ensis }\end{array}$ & $5^{1}$ & $1.68(0.7-4.1)$ & \\
\hline Great horned owl & Bubo virginiatus & 13 & $0.33(0.01-0.73)$ & 0.14 \\
\hline Opossum & $\begin{array}{l}\text { Didelphis virgin- } \\
\text { iana }\end{array}$ & 1 & 0.18 & 0.8 \\
\hline Raccoon & Procyon lotor & 6 & $2.69(0.32-5.3)$ & \\
\hline Raven & Corvus corax & 1 & 1.04 & \\
\hline Red fox & Vulpes vulpes & 2 & $2.67(1.32-4.01)$ & \\
\hline Red-tailed hawk & $\begin{array}{l}\text { Buteo jamaicen- } \\
\text { sis }\end{array}$ & 7 & $0.65(0.23-1.6)$ & \\
\hline Screech owl & Otus asio & 2 & $0.57(0.34-0.8)$ & \\
\hline Skunk & Mephitis mephitis & 3 & & $0.13(0.02-0.28)$ \\
\hline
\end{tabular}

${ }^{1}$ One concentration from colon, $25.8 \mathrm{mg} / \mathrm{kg}$.

Stone et al. (2003) note that anticoagulants appear to be present in the majority of great horned owls, in about half of the red-tailed hawks, and probably in substantial proportions of other raptors in New York State. The poisonings in the red foxes, skunks (Mephitis mephitis), opossums (Didelphis virginiana) and the other raccoons could have been primary or secondary in nature.

Table 11. Range of liver residues of brodifacoum and bromadiolone in four raptor species analyzed by Stone et al. (2003).

\begin{tabular}{llll}
\hline \multirow{2}{*}{ Common name } & Scientific name & \multicolumn{2}{c}{ Liver residues ppm } \\
\cline { 3 - 4 } & & Bromadiolone & Brodifacoum \\
\hline Red-tailed hawk & Buteo jamaicensis & $0.08-0.50$ & $0.006-1.28$ \\
Great horned owl & Bubo virginiatus & & $0.007-0.97$ \\
Screech owl & Otus asio & & $0.007-0.47$ \\
Cooper's hawk & Accipiter cooperii & $0.04-0.60$ & $0.008-0.22$ \\
\hline
\end{tabular}

Hegdal and Colvin (1988) examined the risk of secondary poisoning to eastern screech owls during experimental vole control baiting in orchards during the fall and winter of 1981-82. The study indicated a considerable risk to screech owls and possibly other raptors that feed on voles baited with $10 \mathrm{ppm}(\mathrm{mg} / \mathrm{kg}$ ) brodifacoum bait (baits registered for rat and mouse control are normally $50 \mathrm{ppm}$ ). Liver residue analyses were conducted on 16 owls, and brodifacoum residues were detected at levels ranging from 0.3 to $0.8 \mathrm{mg} / \mathrm{kg}$ in 9 owls.

Howald et al. (1999) examined effects of brodifacoum baiting on avian scavengers during a rat control program on Langara Island, Canada, and concluded that there is a risk of secondary poisoning for some predators and scavengers. The impact on ravens may have been severe. Of an island population of about 20-72 individuals, 13 ravens were found dead 
after 12 to 47 days from beginning of baiting. All dead ravens had brodifacoum residues ranging from 0.98 to $2.52 \mathrm{mg} / \mathrm{kg}$ in their livers. Ravens were likely exposed from eating the bait as well as secondarily feeding on intoxicated prey. Brodifacoum was also detected in a pooled sample of 3 north western crows (Corvux caurinus) collected 12 days after the start of baiting.

Riley et al. (2007) tested bobcats (Lynx rufus) for a disease, notoedric mange, and found out that anticoagulants were present in 35 of 39 (90\%) tested bobcats. Multiple compounds were present in 27 of these animals (77\%). Brodifacoum levels in the livers ranged up to $0.56 \mathrm{mg} / \mathrm{kg}$, bromadiolone $0.82 \mathrm{mg} / \mathrm{kg}$ and difethialone $<0.25 \mathrm{mg} / \mathrm{kg}$. 19 of 19 (100\%) bobcats that died with mange were also exposed to the rodenticides brodifacoum and bromadiolone.

\subsection{New Zealand}

In New Zealand anticoagulants have been used in the elimination of introduced rodents on islands and other areas inhabited by indigenous species found only in New Zealand. These pest control programmes have resulted in the primary and secondary poisoning and sub-lethal contamination of non-target species (Alterio et al. 1996, 1997, 2000; Eason et al.1995, 1999, 2002; Murphy et al.1998a, 1998b).

Birds of at least five indigenous species have been reported killed and lethal or sub-lethal effects have been documented in 26 bird species, as a result of secondary poisoning with brodifacoum after rat-, rabbit- and opossum-poisoning operations (Eason \& Spurr 1995; Hoare \& Hare 2006). Mortality of radio-tagged stoats, ferrets (Mustela furo), weasels, and cats was reported to be even $100 \%$ after brodifacoum application, and secondary adverse effects on Australasian harriers (Circus approximans), New Zealand falcons (Falco novaeseelandiae), rails, brown skuas (Catharacta skua), gulls, and owls (morepork, Ninox novaeseelandiae) have also been reported (Alterio et al. 1997; Eason \& Spurr 1995).

Residues of brodifacoum were detected in $78 \%$ of 40 stoats, $71 \%$ of 14 weasels, and $56 \%$ of 16 ferrets trapped after a rat- and opossumpoisoning operation (Murphy et al. 1998a). Residue levels in stoats were greater during the three months after the removal of baits than during the poison operation. The mean residue level in the livers of weasels was $1.26 \mathrm{mg} / \mathrm{kg}$ and $1.01 \mathrm{mg} / \mathrm{kg}$ in the livers of ferrets. In the study by Alterio (1996), all three radio-tagged stoats and five ferrets, and two of three radio-tagged cats, died shortly after brodifacoum-poisoning in the study area. Liver residues were $0.94-1.72 \mathrm{mg} / \mathrm{kg}$ in stoats, $1.47-1.97 \mathrm{mg} / \mathrm{kg}$ in ferrets and 2.71-3.73 $\mathrm{mg} / \mathrm{kg}$ in cats. The last cat was trapped, and had brodifacoum residues of $2.7 \mathrm{mg} / \mathrm{kg}$ in the liver. At least six stoats are also likely to be killed because of the poisoning. In 2000, Alterio \& Moller 
reported deaths of nine of ten radio-tagged stoats after a poisoning operation with brodifacoum. Six of the stoats died 1-2 weeks after scavenging on poisoned carcasses.

In a pen trial, one out of four Australasian harriers died after eating rabbits poisoned with brodifacoum (Godfrey 1985, in Eason \& Spurr 1995). Eason and Spurr (1995) also note that bats that are primarily insectivorous may be at risk from both primary and secondary poisoning. Besides of eating baits, they eat carrions and might feed on brodifacoumpoisoned insects or carcasses. 


\section{Conclusions and implications to the Nordic countries}

The existence of substantial incident data along with liver-residue analyses confirms that birds and non-target mammals are being exposed to anticoagulant rodenticides all around the world. The fact that numerous species of birds and mammals, including predators and scavengers have been exposed to these substances indicates that both primary and secondary exposure is occurring. Exposure of non-target animals is likely to be more widespread than the number of reported incidents suggests. Most surveys have been based on the activity of the general public who has sent carcasses to analysis when they have suspected poisoning. In many situations carcasses might not be detected, death may be attributed to natural mortality, or an incident may not be reported for a variety of reasons. In conclusion, studies made on secondary exposure reveal only the top of the iceberg. Residues found in predators and scavengers show that predominantly the second generation substances, i.e. brodifacoum, bromadiolone, difenacoum, flocoumafen and difethialone, cause secondary exposure. There were not many incidents where first generation anticoagulants were involved. The frequency of incidents is assumed to correlate to the use volumes of the substances. Unfortunately we have not found published data on sale volumes that could be compared to the number of incidents in the UK and US where most incident data are available. The statistics on sale volumes or use frequencies would enable the comparison of the likelihood or potency of the substances in causing the secondary poisoning. Due to lack of resources and/or ignorance of the potential risk measurements have been made only in few countries, and the incidents are likely to be much more widespread than reported here.

The available data show that more attention should be paid to the use of second generation anticoagulant rodenticides. Several risk reduction measures have been suggested (see 2.4.2), but it is uncertain how efficient these measures are or to what extent these measures are applied in practice. Maybe more education on potential risks and risk management should be directed to the users of anticoagulants. The use of second generation anticoagulants should be restricted to situations where they cannot be replaced by first generation substances or alternative methods. In general, use of mechanical traps and other non-biocidal methods should be prioritized in homes where mice are the main target animals. It is imperative that the use of second generation anticoagulants is restricted to well organised, strictly time-limited campaigns where the number of target animals is carefully monitored in order to obtain optimal eradication and 
minimise the treatment time period. Extended use beyond the time needed for optimal effect must be avoided. Control of larger rat infestations is challenging and should be left to professional pest control operators. Residue-monitoring programmes could be established in those countries where anticoagulants are used in the field or extensively around farm buildings.

In the UK, the only EU country where residues of anticoagulant have been more systematically measured, the most commonly indirectly exposed species were red kite, fox and buzzard (Table 12). Secondary exposure to anticoagulants does most likely occur also in the Nordic countries, although there are hardly any incident studies to be found. In Denmark, anticoagulant rodenticide residues were detected in 4 of 5 red kites, 11 of 22 barn owls and 1 of 2 common kestrels (Laursen 2008, unpublished master study). Bromadiolone and brodifacoum were most frequently detected in red kites and barn owls, one red kite having detectable residues from three and two barn owls having residues of two different anticoagulant rodenticides. The data indicate that anticoagulant residues may occur in a great proportion of raptors, although the sample size was too small for making statistically valid conclusions.

The most commonly exposed predatory species in the UK (Table 12) occur also in the Nordic countries and would be appropriate candidates to start the measurements of anticoagulant residues, if a monitoring project would be initiated. The species potentially exposed either directly or indirectly to anticoagulants in the Nordic countries are given in Attachment A. The species were selected by the experts from the Nordic countries.

Table 12. The most commonly exposed non-target species in the UK and percentage of animals with residues.

\begin{tabular}{lrrl}
\hline Species & Percentage with residues & No. of individuals studied & Reference \\
\hline Red kite & 74 & 23 & Walker et al. 2008b \\
Fox & 57 & 23 & WIIS \\
Buzzard & 61 & WIIS \\
Polecat & 37 & 100 & Shore et al. 1993, 2003 \\
Weasel & 31 & 10 & McDonald et al. 1998 \\
Barn owl & 30 & 557 & Newton et al. 1990 \\
Stoat & 24 & 40 & McDonald et al. 1998 \\
\hline
\end{tabular}




\section{References}

Alterio, N. (1996). Secondary poisoning of stoats (Mustela erminea), feral ferrets (Mustela furo), and feral house cats (Felis catus) by the anticoagulant poison, brodifacoum. New Zealand Journal of Zoology 23(4): 331-338.

Alterio, N., Brown, K. and Moller, H. (1997). Secondary poisoning of mustelids in a New Zealand Nothofagus forest. Journal of Zoology 243: 863869.

Alterio, N. and Moller, H. (2000). Secondary poisoning of stoats (Mustela erminea) in a South Island podocarp forest, New Zealand: implications for conservation. Wildlife Research 27(5): 501-508.

Atterby, H., Kerins, G. M. and MacNicoll, A. D. (2005). Whole-carcass residues of the rodenticide difenacoum in anticoagulant-resistant and -susceptible rat strains (Rattus norvegicus). Environmental Toxicology and Chemistry 24(2): 318-323.

Barnett, E. A., Fletcher, M. R., Hunter, K. and Sharp, E. A. (1999). Pesticide Poisoning of Animals 1998: Investigations of Suspected Incidents in the United Kingdom. A Report of the Environmental Panel of the Advisory Committee on Pesticides.

Barnett, E. A., Fletcher, M. R., Hunter, K. and Sharp, E. A. (2000). Pesticide Poisoning of Animals 1999: Investigations of Suspected Incidents in the United Kingdom. A Report of the Environmental Panel of the Advisory Committee on Pesticides.

Barnett, E. A., Fletcher, M. R., Hunter, K. and Sharp, E. A. (2002a). Pesticide Poisoning of Animals 2000: Investigations of Suspected Incidents in the United Kingdom. A Report of the Environmental Panel of the Advisory Committee on Pesticides.

Barnett, E. A., Fletcher, M. R., Hunter, K. and Sharp, E. A. (2002b). Pesticide Poisoning of Animals 2001: Investigations of Suspected Incidents in the United Kingdom. A Report of the Envi- ronmental Panel of the Advisory Committee on Pesticides.

Barnett, E. A., Fletcher, M. R., Hunter, K. and Sharp, E. A. (2003). Pesticide Poisoning of Animals 2002: Investigations of Suspected Incidents in the United Kingdom. A Report of the Environmental Panel of the Advisory Committee on Pesticides.

Barnett, E. A., Fletcher, M. R., Hunter, K. and Sharp, E. A. (2004). Pesticide Poisoning of Animals 2003: Investigations of Suspected Incidents in the United Kingdom. A Report of the Environmental Panel of the Advisory Committee on Pesticides.

Barnett, E. A., Fletcher, M. R., Hunter, K. and Sharp, E. A. (2005). Pesticide Poisoning of Animals 2004: Investigations of Suspected Incidents in the United Kingdom. A Report of the Environmental Panel of the Advisory Committee on Pesticides.

Barnett, E. A., Fletcher, M. R., Hunter, K. and Sharp, E. A. (2006). Pesticide Poisoning of Animals 2005: Investigations of Suspected Incidents in the United Kingdom. A Report of the Environmental Panel of the Advisory Committee on Pesticides.

Barnett, E. A., Fletcher, M. R., Hunter, K. and Sharp, E. A. (2007). Pesticide Poisoning of Animals 2006: Investigations of Suspected Incidents in the United Kingdom. A Report of the Environmental Panel of the Advisory Committee on Pesticides.

Barnett, E. A., Fletcher, M. R., Hunter, K. and Sharp, E. A. (2008). Pesticide Poisoning of Animals 2007: Investigations of Suspected Incidents in the United Kingdom. A Report of the Environmental Panel of the Advisory Committee on Pesticides.

Berny, P. J., Buronfosse, T., Buronfosse, F., Lamarque, F. And Lorgue, G. (1997). Field evidence of secondary poisoning of foxes (Vulpes vulpes) and buzzards (Buteo buteo) by bromadiolone, a 4-year survey. Chemosphere 35(8): 1817-1829. 
Berny, P. J. (2007). Pesticides and the intoxication of wild animals. Journal of Veterinary Pharmacology and Therapeutics 30: 93-100.

Berny, P. J. and Gaillet, J. R. (2008). Acute poisoning of Red Kites (Milvus milvus) in France: Data from the SAGIR network. Journal of Wildlife Diseases 44(2): 417-426.

Birks, J. D. S. (1998). Secondary rodenticide poisoning risk arising from winter farmyard use by the European polecat Mustela putorius. Biological Conservation 85(3): 233-240.

Brakes, C. R. and Smith, R. H. (2005). Exposure of non-target small mammals to rodenticides: short-term effects, recovery and implications for secondary poisoning. Journal of Applied Ecology 42(1): 118-128.

Dowding, C.V., Shore, R.F., Worgan A., Baker P.J. and Harris S. (2010). Accumulation of anticoagulant rodenticides in a non-target insectivore, the European hedgehog (Erinaceus europaeus). Environmental Pollution 158(1): 161-166.

Eason, C. T. and Spurr, E. B. (1995). Review of the toxicity and impacts of brodifacoum on non-target wildlife in New Zealand. New Zealand Journal of Zoology 22(4): 371-379.

Eason, C. T., Milne, L., Potts, M., Morriss, G., Wright G. R. G. and Sutherland O. R. W. (1999). Secondary end tertiary poisoning risks associated with brodifacoum. New Zealand Journal of Ecology 23(2): 219-224.

Eason, C. T., Murphy, E. C., Wright, G. R. G. and Spurr, E. B. (2002). Assessment of risks of brodifacoum to nontarget birds and mammals in New Zealand. Ecotoxicology 11(1): 35-48.

Erickson, W. and Urban, D. (2004). Potential Risk of Nine Rodenticides to Birds and Mammals: A Comparative Approach. Washington DC, United States Environmental Protection Agency: 192.

Fournier-Chambrillon, C., Berny, P. J., Coiffier, O., Barbedienne, P., Dasse, B., Delas, G., Galineau, H., Mazet, A., Pouzenc, P., Rosoux, R. and Fournier, P. (2004). Evidence of secondary poisoning of free-ranging riparian mustelids by anticoagulant rodenticides in France: Implications for conservation of European mink (Mustela lutreola).
Journal of Wildlife Diseases 40(4): 688-695.

Giraudoux, P., Tremollieres, C., Barbier, B., Defaut, R., Rieffel, D., Bernard, N., Lucot, E. and Berny, P. (2006). Persistence of bromadiolone anticoagulant rodenticide in Arvicola terrestris populations after field control. Environmental Research 102(3): 291-298.

Hegdal, P. L. and Colvin, B. A. (1988). Potential hazard to eastern screech owls and other raptors of brodifacoum bait used for vole control in orchards. Environmental Toxicology and Chemistry 7(3): 245-260.

Hoare, J. M. and Hare, K. M. (2006). The impact of brodifacoum on non-target wildlife: gaps in knowledge. New Zealand Journal of Ecology 30(2): 157167.

Hooker, S. and Innes, J. (1995). Ranging behaviour of forest-dwelling ship rats, Rattus rattus, and effects of poisoning with brodifacoum. New Zealand Journal of Zoology 22(3): 291-304.

Howald, G. R., Mineau, P., Elliott, J. E. and Cheng, K. M. (1999). Brodifacoum poisoning of avian scavengers during rat control on a seabird colony. Ecotoxicology 8(6): 431-447.

Huckle, K. R., Hutson, D. H. and Warburton, P. A. (1988). Elimination and accumulation of the rodenticide flocoumafen in rats following repeated oraladministration. Xenobiotica 18(12): 1465-1479.

Huckle, K. R., Hutson, D. H., Logan, C. J., Morrison, B. J. and Warburton, P. A (1989). The fate of the rodenticide flocoumafen in the rat - retention and elimination of a single oral dose. Pesticide Science 25(3): 297-312.

IPCS 1995. Environmental Health Criteria 175. Anticoagulant Rodenticides. International Programme on Chemical Safety. World Health Organization. ISBN 924157175 6, ISSN 0250-863X.

Koivisto, I. (ed) (1983). Suomen eläimet. Osa 1. Weilin+Göös, Espoo. ISBN 951-35-2730-1.

Lambert, O., Pouliquen, H., Larhantec, M., Thorin, C. and L'Hostis, M. (2007). Exposure of raptors and waterbirds to anticoagulant rodenticides (Difenacoum, bromadiolone, coumatetralyl, coumafen, brodifacoum): Epidemiological survey in Loire Atlantique (France). Bulletin of Environmental 
Contamination and Toxicology 79(1): 91-94.

Larsen J. (2003). Emission Scenario Document for Biocides Used as Rodenticides. EUBEES.

Laursen, I. M. (2008). Environmental Contamination, Blood Parasites, and Home Range of the Red Kite (Milvus milvus) in Denmark. Master of Science Thesis in Biology. Department of Biology, Faculty of Science, University of Copenhagen.

Lodal, J. and Hansen, O. C. (2002). Human and Environmental Exposure Scenarios for Rodenticides - Focus on the Nordic countries. TemaNord 2002:575. Nordic Council of Ministers, Copenhagen. ISBN 92-893-0842-7, ISSN 09086692.

McDonald, R. A., Harris, S., Turnbull, G., Brown, P. and Fletcher, M. (1998). Anticoagulant rodenticides in stoats (Mustela erminea) and weasels (Mustela nivalis) in England. Environmental Pollution 103(1): 17-23.

McDonald, R. A. and Harris, S. (2000). The use of fumigants and anticoagulant rodenticides on game estates in Great Britain. Mammal Rev. 30(1): 57-64.

Moran, S. (2001). The use of dyes as visual deterrents to pesticide-treated baits and seeds by grain-eating birds. In Pelz, H.-J., Cowan, D.P. and Feare, C.J. editors. Advances in vertebrate pest management II, Filander Verlag, Fürth, p. 91-102.

Mendenhall, V.M. and Pank, L.F. 1980. Secondary poisoning of owls by anticoagulant rodenticides. Wildlife Society Bulletin 8:311-315.

Murphy, E. C., Clapperton, B. K., Bradfield, P. M. F. and Speed, H. J. (1998a). Brodifacoum residues in target and non-target animals following large-scale poison operations in New Zealand podocarp-hardwood forests. New Zealand Journal of Zoology 25(4): 307-314.

Murphy, E. C., Clapperton, B. K., Bradfield, P. M. F. and Speed, H. J. (1998b). Effects of rat-poisoning operations on abundance and diet of mustelids in New Zealand podocarp forests. New Zealand Journal of Zoology 25(4): 315-328.

Newton, I., Wyllie, I. and Freestone, P. (1990). Rodenticides in British Barn
Owls. Environmental Pollution, 68, 101-117.

Newton, I., Wyllie, I., Gray, A. and Eadsforth, C. V. (1994). The toxicity of the rodenticide flocoumafen to barn owls and its elimination via pellets. Pesticide science 41(3):187-193.

Newton, I., Wyllie, I. and Dale, L. (1997). Mortality Causes in British Barn Owls (Tyto alba), Based on 1,101 Carcasses Examined during 1963-1996. In Duncan, J. R., Johnson, D. H., Nicholls, T. H. editors. Biology and Conservation of Owls in the Northern Hemisphere, Winnipeg, Canada. United States Department of Agriculture, p. 299-307.

Perrin, C. (1987). New generation guide to birds of Britain and Europe. William Collins Sons \& Co. Ltd, Glasgow. ISBN 0002197693

Riley, S. P. D., Bromley, C., Poppenga, R. H., Uzal, F. A., Whited, L. and Sauvajot, R. M.. (2007). Anticoagulant exposure and notoedric mange in bobcats and mountain lions in urban southern California. Journal of Wildlife Management 71(6): 1874-1884.

Sage, M., Caeurdassier, M., Defaut, R., Gimbert, F., Berny, P. and Giradoux, P. (2008). Kinetics of bromadiolone in rodent populations and implications for predators after field control of the water vole, Arvicola terrestris. Science of the Total Environment 407(1): 211-222.

Shawyer, C. and Banks, P. (1987). Barn Owls on the Brink. New Scientist 116(1591): 30-33.

Shore, R. F., Birks, J. D. S., Freestone, P. and Kitchener, A. C. (1996). Second generation rodenticides and polecats (Mustela putorius) in Britain. Environmental Pollution 91(3): 279-282.

Shore, R. F., Birks, J. D. S. and Freestone, P. (1999). Exposure of non-target vertebrates to second generation rodenticides in Britain, with particular reference to the polecat Mustela putorius. New Zealand Journal of Ecology 23(2): 199206.

Shore, R. F., Birks, J. D. S., Afsar, A., Wienburg, C. L. and Kitchener, A. C. (2003). Spatial and temporal analysis of second generation anticoagulant rodenticide residues in polecats (Mustela putorius) from throughout their range in Britain, 1992-1999. Environmental Pollution 122(2): 183-193. 
Stone, W. B., Okoniewski, J. C. and Stedelin, J. R. (1999). Poisoning of wildlife with anticoagulant rodenticides in New York. Journal of Wildlife Diseases 35(2): 187-193.

Stone, W. B., Okoniewski, J. C. and Stedelin, J. R. (2003). Anticoagulant rodenticides and raptors: Recent findings from New York, 1998-2001. Bulletin of Environmental Contamination and Toxicology 70(1): 34-40.

TGD 2003. Technical Guidance Document on Risk Assessment in Support of Commission Directive 93/67/EEC on Risk Assessment for New Notified Substances, Commission Regulation (EC) No 1488/94 on Risk Assessment for Existing Substances, Directive 98/8/EC of the European Parliament and of the Council Concerning the Pla- cing of Biocidal Products on the Market. Part II. European Commission.

Tuyttens, F. A. M. and Stuyck, J. (2002). Effectiveness and efficiency of chlorophacinone poisoning for the control of muskrat (Ondatra zibethicus) populations. New Zealand Journal of Zoology 29(1): 33-40.

Walker, L. A., Turk, A., Long, S. M., Wienburg, C. L., Best, J. and Shore, R. F. (2008a). Second generation anticoagulant rodenticides in tawny owls (Strix aluco) from Great Britain. Science of the Total Environment 392(1): 93-98.

Walker, L.A., Shore, R. F., Turk, A., Pereira M.G. and Best J. (2008b). The Predatory Bird Monitoring Scheme: Identifying Chemical Risks to Top Predators in Britain. Ambio 37(6): 466-471. 


\section{Sammanfattning}

Antikoagulant rodenticider har hittats i icke-måldjur i alla delar av världen där man har mätt rester. Brodifakum, bromadiolon, difenakum, flokumafen och difetialon betraktas som andra generationens antikoagulant rodenticider. De har kommit ut på marknaden sedan målgnagarna hade blivit resistenta mot warfarin och övriga första generationens anticoagulant rodenticider. Andra generationens antikoagulanter är giftigare och mera persistenta i gnagare jämfört med första generationens medel. Därför har de en tendens att ackumuleras i icke-måldjur som äter gnagare. Trots omfattande användning av antikoagulanter för bekämpning av råttor och möss, finns det relativt få publikationer om antikoagulater i ickemåldjuren. Resterna har studerats systematiskt bara i Storbritannien och i vissa delstater i USA. I Europa har antikoagulantrester mätts förutom i Storbritannien bara i Frankrike. I Storbritannien, har antikoagulantresterna studerats framförallt i tornuggla (Tyto alba) och i iller (Mustela putorius). Ungefär en tredjedel av de studerade exemplaren innehöll rester. Antikoagulanthalterna har oftast varit subletala. Vi vet inte hur sådana låga halter påverkar djuren. I Storbritannien har man också hittat rester av antikoagulanter bl.a. i ormvråk (Buteo buteo), röd glada (Milvus milvus), och räv (Vulpes vulpes). I USA har man hittat antikoagulanter i virginauv (Bubo virginianus), rödstjärtad vråk (Buteo jamaicensis), prärievarg, räv och tvättbjörn. Antikoagulanter är de mest använda rodenticiderna i de nordiska länderna, men det finns ingen publicerad information om rester av antikoagulanter i icke-måldjur. Information om halterna behövs för att kunna värdera effektiviteten av de metoder som används för att minska riskerna som är förbundna med rodenticider och för att kunna avgöra om det behövs ytterligare åtgärder. 



\section{Attachment A}

Table 1. List of birds in the Nordic countries which may potentially be exposed to anticoagulant rodenticides. The information on diet is obtained from Perrins (1987).

\begin{tabular}{|c|c|c|c|c|}
\hline Scientific name & English name & $\begin{array}{l}\text { Swedish } \\
\text { name }\end{array}$ & Main food & Country \\
\hline Accipiter gentilis & Goshawk & Duvhök & $\begin{array}{l}\text { Medium-size birds and } \\
\text { mammals }\end{array}$ & $\mathrm{D}, \mathrm{F}, \mathrm{N}, \mathrm{S}$ \\
\hline Accipter nisus & Sparrowhawk & Sparvhök & $\begin{array}{l}\text { Small birds, to a lesser } \\
\text { extent small mammals }\end{array}$ & $\mathrm{D}, \mathrm{F}, \mathrm{N}, \mathrm{S}$ \\
\hline Aquila chrysaetos & Golden eagle & Kungsörn & $\begin{array}{l}\text { Hare, gamebirds, } \\
\text { carcasses }\end{array}$ & $\mathrm{D}, \mathrm{F}, \mathrm{N}, \mathrm{S}$ \\
\hline Buteo buteo & Buzzard & Ormvråk & $\begin{array}{l}\text { Small mammals, frogs, } \\
\text { snakes, lizards }\end{array}$ & $\mathrm{D}, \mathrm{F}, \mathrm{N}, \mathrm{S}$ \\
\hline Buteo lagopus & $\begin{array}{l}\text { Rough-legged } \\
\text { buzzard }\end{array}$ & Fjällvråk & Lemmings, voles & $\mathrm{D}, \mathrm{F}, \mathrm{N}, \mathrm{S}$ \\
\hline Circus aeruginosus & Marsh harrier & Brun kärrhök & $\begin{array}{l}\text { Water voles, frogs, } \\
\text { young of water birds }\end{array}$ & $\mathrm{D}, \mathrm{F}, \mathrm{N}, \mathrm{S}$ \\
\hline Falco peregrinus & Peregrine falcon & Pilgrimsfalk & Birds & $\mathrm{D}, \mathrm{F}, \mathrm{N}, \mathrm{S}$ \\
\hline Falco tinnunculus & Kestrel & Tornfalk & $\begin{array}{l}\text { Predominantly small } \\
\text { rodents }\end{array}$ & $\mathrm{D}, \mathrm{F}, \mathrm{N}, \mathrm{S}$ \\
\hline Haliaeetus albicilla & White-tailed eagle & Havsörn & $\begin{array}{l}\text { Fish, water birds, } \\
\text { carcasses }\end{array}$ & $\mathrm{D}, \mathrm{F}, \mathrm{N}, \mathrm{S}$ \\
\hline Milvus milvus & Red kite & Röd glada & $\begin{array}{l}\text { Fish, carcasses, } \\
\text { insects }\end{array}$ & $\mathrm{D}, \mathrm{N}, \mathrm{S}$ \\
\hline Aegolius funereus & Tengmalm's owl & Pärluggla & $\begin{array}{l}\text { Predominantly small } \\
\text { mammals }\end{array}$ & $\mathrm{D}, \mathrm{F}, \mathrm{N}, \mathrm{S}$ \\
\hline Asio otus & Long-eared owl & Hornuggla & Small rodents & $\mathrm{D}, \mathrm{F}, \mathrm{N}, \mathrm{S}$ \\
\hline Bubo bubo & Eagle owl & Berguv & Mammals, birds, frogs & $\mathrm{D}, \mathrm{F}, \mathrm{N}, \mathrm{S}$ \\
\hline $\begin{array}{l}\text { Bubo scandiacus } \\
\text { (Nyctea scandiaca) }\end{array}$ & Snowy owl & Fjälluggla & $\begin{array}{l}\text { Lemmings, voles, } \\
\text { willow grouse }\end{array}$ & $\mathrm{F}, \mathrm{N}, \mathrm{S}$ \\
\hline Strix aluco & Tawny owl & Kattuggla & $\begin{array}{l}\text { Small mammals, birds, } \\
\text { insects }\end{array}$ & $\mathrm{D}, \mathrm{F}, \mathrm{N}, \mathrm{S}$ \\
\hline Tyto alba & Barn owl & Tornuggla & $\begin{array}{l}\text { Small mammals, frogs, } \\
\text { insects }\end{array}$ & $\mathrm{D}, \mathrm{N}, \mathrm{S}$ \\
\hline Corvus corone cornix & Hooded crow & Kråka & Waste, dead animals & $\mathrm{D}, \mathrm{F}, \mathrm{N}, \mathrm{S}$ \\
\hline Corvus corax & Raven & Korp & $\begin{array}{l}\text { Omnivorous, carcasses } \\
\text { in winter }\end{array}$ & $\mathrm{D}, \mathrm{F}, \mathrm{N}, \mathrm{S}$ \\
\hline Corvus monedula & Jackdaw & Kaja & Small animals & $\mathrm{D}, \mathrm{F}, \mathrm{N}, \mathrm{S}$ \\
\hline Pica pica & Magpie & Skata & Omnivorous & $\mathrm{D}, \mathrm{F}, \mathrm{N}, \mathrm{S}$ \\
\hline Larus argentatus & Herring gull & Gråtrut & $\begin{array}{l}\text { Dead fish, young of } \\
\text { water birds, waste }\end{array}$ & $\mathrm{D}, \mathrm{F}, \mathrm{N}, \mathrm{S}$ \\
\hline Larus canus & Common gull & Fiskmås & $\begin{array}{l}\text { Dead fish, insects, } \\
\text { waste }\end{array}$ & $\mathrm{D}, \mathrm{F}, \mathrm{N}, \mathrm{S}$ \\
\hline Larus marinus & $\begin{array}{l}\text { Great black- } \\
\text { backed gull }\end{array}$ & Havstrut & $\begin{array}{l}\text { Young of water birds, } \\
\text { fish, mussels }\end{array}$ & $\mathrm{D}, \mathrm{F}, \mathrm{N}, \mathrm{S}$ \\
\hline Larus ridibundus & Black-headed gull & Skrattmås & $\begin{array}{l}\text { Insects, earthworms, } \\
\text { molluscs, }\end{array}$ & $\mathrm{D}, \mathrm{F}, \mathrm{N}, \mathrm{S}$ \\
\hline Carduelis chloris & Greenfinch & Grönfink & Seed & $\mathrm{D}, \mathrm{F}, \mathrm{N}, \mathrm{S}$ \\
\hline Columba livia & Rock dove & Tamduva & $\begin{array}{l}\text { Seed, grain, food } \\
\text { waste }\end{array}$ & $\mathrm{D}, \mathrm{F}, \mathrm{N}, \mathrm{S}$ \\
\hline Emberiza calandra & Corn bunting & Kornsparv & Small seeds, insects & $\mathrm{D}, \mathrm{N}, \mathrm{S}$ \\
\hline Emberiza citrinella & Yellow-hammer & Gulsparv & Seed, grain, insects & $\mathrm{D}, \mathrm{F}, \mathrm{N}, \mathrm{S}$ \\
\hline Galerida cristata & Crested lark & Tofslärka & Insects, small seeds & $D, N, S$ \\
\hline Passer domesticus & House sparrow & Gråsparv & Seed, food waste & $\mathrm{D}, \mathrm{F}, \mathrm{N}, \mathrm{S}$ \\
\hline Passer montanus & Tree sparrow & Pilfink & $\begin{array}{l}\text { Omnivorous, predomi- } \\
\text { nantly seed }\end{array}$ & $D, F, N, S$ \\
\hline Streptopelia decaocto & Collared dove & Turkduva & Seed, grain, berries & $\mathrm{D}, \mathrm{F}, \mathrm{N}, \mathrm{S}$ \\
\hline
\end{tabular}


Table 2. List of mammals in the Nordic countries which may potentially be exposed to anticoagulant rodenticides. The information on diet is obtained from Koivisto (1983).

\begin{tabular}{|c|c|c|c|c|}
\hline Latin name & English name & $\begin{array}{l}\text { Swedish } \\
\text { name }\end{array}$ & Main food & Country \\
\hline $\begin{array}{l}\text { Apodemus } \\
\text { flavicollis }\end{array}$ & $\begin{array}{l}\text { Yellow-necked } \\
\text { mouse }\end{array}$ & $\begin{array}{l}\text { Större } \\
\text { skogsmus }\end{array}$ & Seed, grain & $\mathrm{D}, \mathrm{F}, \mathrm{N}, \mathrm{S}$ \\
\hline $\begin{array}{l}\text { Apodemus } \\
\text { sylvaticus }\end{array}$ & Wood mouse & $\begin{array}{l}\text { Mindre } \\
\text { skogsmus }\end{array}$ & Seed, grain & $\mathrm{D}, \mathrm{F}, \mathrm{N}, \mathrm{S}$ \\
\hline Arvicola terrestris & Water vole & Vattensork & Seed, grain & $\mathrm{D}, \mathrm{F}, \mathrm{N}, \mathrm{S}$ \\
\hline $\begin{array}{l}\text { Clethrionomys } \\
\text { glareolus }\end{array}$ & Bank vole & Ängsork & Seed, grain & \\
\hline Microtus agrestis & Field vole & Åkersork & Seed, grain & $\mathrm{D}, \mathrm{F}, \mathrm{N}, \mathrm{S}$ \\
\hline Mustela erminea & Stoat & Hermelin & Small rodents & $\mathrm{D}, \mathrm{F}, \mathrm{N}, \mathrm{S}$ \\
\hline Mustela nivalis & Least weasel & Snövessla & Small rodents & $\mathrm{D}, \mathrm{F}, \mathrm{N}, \mathrm{S}$ \\
\hline Mustela putorius & Polecat & Iller & Small rodents, fish, frogs, birds & $\mathrm{D}, \mathrm{F}, \mathrm{N}, \mathrm{S}$ \\
\hline Mustela vison & American mink & Mink & $\begin{array}{l}\text { Fish, small rodents, frogs, crayfish, } \\
\text { birds, carcasses }\end{array}$ & $D, F, N, S$ \\
\hline Martes martes & Pine marten & Mård & $\begin{array}{l}\text { Squirrel, hare, small mammals, } \\
\text { muskrat, gamebirds, insects, berries }\end{array}$ & $\mathrm{D}, \mathrm{F}, \mathrm{N}, \mathrm{S}$ \\
\hline Meles meles & Badger & Grävling & Omnivorous, small vertebrates & $\mathrm{D}, \mathrm{F}, \mathrm{N}, \mathrm{S}$ \\
\hline Lutra lutra & Otter & Utter & Fish, small mammals, birds & $D, F, N, S$ \\
\hline Vulpes vulpes & Fox & Räv & Small rodents, carcasses, waste & $\mathrm{D}, \mathrm{F}, \mathrm{N}, \mathrm{S}$ \\
\hline $\begin{array}{l}\text { Nyctereutes } \\
\text { procyonoides }\end{array}$ & Raccoon dog & Mårdhund & Small mammals, fish, frogs & $\mathrm{F}, \mathrm{N}, \mathrm{S}$ \\
\hline Sciurus vulgaris & Squirrel & Ekorre & $\begin{array}{l}\text { Seed, grain, berries, birds and } \\
\text { eggs }\end{array}$ & $D, F, N, S$ \\
\hline
\end{tabular}




\section{Attachment B}

Table 1. Number of species with anticoagulant residues. WIIS and EIIS data are excluded from the summary.

\begin{tabular}{|c|c|c|c|c|c|}
\hline Scientific name & Common name & Substance & $\begin{array}{l}\text { No. with } \\
\text { residues }\end{array}$ & $\begin{array}{r}\text { Range of } \\
\text { residues in } \\
\text { liver, } \mathrm{mg} / \mathrm{kg}\end{array}$ & Reference \\
\hline Accipiter cooperii & Cooper's hawk & Bromadiolone & 5 & $0.04-0.6$ & Stone et al. 2003 \\
\hline Accipiter cooperii & Cooper's hawk & Brodifacoum & 12 & $0.008-0.22$ & Stone et al. 2003 \\
\hline Accipiter striatus & $\begin{array}{l}\text { Sharp-shinned } \\
\text { hawk }\end{array}$ & $\begin{array}{l}\text { Brodifacoum, } \\
\text { bromadiolone }\end{array}$ & 1 & & Stone et al. 2003 \\
\hline $\begin{array}{l}\text { Aegolius } \\
\text { acadicus }\end{array}$ & Saw-whet owl & & 1 & & Stone et al. 2003 \\
\hline Aquila chrysaetos & Golden eagle & Brodifacoum & 1 & 1.04 & Stone et al. 1999 \\
\hline Ardea cinerea & Heron & Bromadiolone & 1 & 0.2 & Berny et al. 1997 \\
\hline Asio otus & Long-eared owl & & 2 & & Stone et al. 2003 \\
\hline Asio otus & Long-eared owl & Brodifacoum & 1 & & Hegdal \& Colvin 1988 \\
\hline Bubo virginianus & Great-horned owl & & 56 & & $\begin{array}{l}\text { Stone et al. 1999, } \\
2003\end{array}$ \\
\hline Buteo buteo & Eurasian buzzard & Bromadiolone & 15 & $0.2-1.3$ & Berny et al. 1997 \\
\hline Buteo buteo & Eurasian buzzard & Brodifacoum & 1 & & Lambert et al. 2007 \\
\hline Buteo buteo & Eurasian buzzard & Bromadiolone & 5 & & Lambert et al. 2007 \\
\hline Buteo buteo & Eurasian buzzard & Difenacoum & 3 & & Lambert et al. 2007 \\
\hline Buteo buteo & Eurasian buzzard & Brodifacoum & 1 & & Shore et al. 2006 \\
\hline Buteo buteo & Eurasian buzzard & Bromadiolone & 2 & & Shore et al. 2006 \\
\hline Buteo buteo & Eurasian buzzard & Difenacoum & 13 & & Shore et al. 2006 \\
\hline Buteo buteo & Eurasian buzzard & Flocoumafen & 1 & & Shore et al. 2006 \\
\hline $\begin{array}{l}\text { Buteo jamaicen- } \\
\text { sis }\end{array}$ & Red-tailed hawk & & 45 & & Stone et al. 2003 \\
\hline $\begin{array}{l}\text { Buteo jamaicen- } \\
\text { sis }\end{array}$ & Red-tailed hawk & Brodifacoum & 7 & $0.23-1.6$ & Stone et al. 1999 \\
\hline Cathartes aura & Turkey vulture & $\begin{array}{l}\text { Brodifacoum, } \\
\text { bromadiolone }\end{array}$ & 2 & & Stone et al. 2003 \\
\hline $\begin{array}{l}\text { Circus approxi- } \\
\text { mans }\end{array}$ & $\begin{array}{l}\text { Australasian } \\
\text { harrier }\end{array}$ & Bromadiolone & 1 & & Berny et al. 1997 \\
\hline $\begin{array}{l}\text { Circus approxi- } \\
\text { mans }\end{array}$ & $\begin{array}{l}\text { Australasian } \\
\text { harrier }\end{array}$ & Brodifacoum & 2 & $0.61-0.66$ & Eason et al. 2002 \\
\hline Circus pygargus & $\begin{array}{l}\text { Harrier (suo- } \\
\text { haukka) }\end{array}$ & Bromadiolone & 1 & $6.1^{2}$ & Berny et al. 1997 \\
\hline Corvus caurinus & $\begin{array}{l}\text { Northwestern } \\
\text { crow }\end{array}$ & Brodifacoum & 1 & 0.048 & Howald et al. 1999 \\
\hline Corvus corax & Raven & Brodifacoum & 1 & 1.04 & Stone et al. 1999 \\
\hline Corvus corax & Raven & Brodifacoum & 13 & $0.98-2.52$ & Howald et al. 1999 \\
\hline Corvus corone & Common crow & Brodifacoum & 1 & 1.34 & Stone et al. 1999 \\
\hline Falco peregrinus & Peregrine falcon & $\begin{array}{l}\text { Brodifacoum, } \\
\text { bromadiolone }\end{array}$ & 1 & & Stone et al. 2003 \\
\hline Falco tinnunculus & Kestrel & & 49 & & Walker et al. $2008 \mathrm{~b}$ \\
\hline Falco tinnunculus & Kestrel & & 24 & & Shore et al. 2001 \\
\hline Falco tinnunculus & Kestrel & Brodifacoum & 2 & & Lambert et al. 2007 \\
\hline Falco tinnunculus & Kestrel & Bromadiolone & 2 & & Lambert et al. 2007 \\
\hline Felis catus & Cat & Brodifacoum & 2 & $0.39-1.4$ & Murphy et al. 1998 \\
\hline Felis catus & Cat & Brodifacoum & 3 & & Alterio 1996 \\
\hline Felis catus & Cat & Brodifacoum & 57 & $0.078-1.84$ & Eason et al. 2002 \\
\hline $\begin{array}{l}\text { Haliaeetus } \\
\text { leucocephalus }\end{array}$ & Bald eagle & Brodifacoum & 3 & $0.037-1.74^{1}$ & Howald et al. 1999 \\
\hline $\begin{array}{l}\text { Haliaeetus } \\
\text { leucocephalus }\end{array}$ & Bald eagle & & 1 & & Stone et al. 2003 \\
\hline Lutra lutra & European otter & Bromadiolone & 2 & $6.0-7.1$ & $\begin{array}{l}\text { Fournier-Chambrillon } \\
\text { et al. } 2004\end{array}$ \\
\hline Lynx lynx & Lynx & Bromadiolone & 1 & $1.3^{2}$ & Berny et al. 1997 \\
\hline Lynx rufus & Bobcat & & 54 & & Riley et al. 2007 \\
\hline Martes foina & Stone-marten & Bromadiolone & 2 & $0.6-1.0^{2}$ & Berny et al. 1997 \\
\hline
\end{tabular}




\begin{tabular}{|c|c|c|c|c|c|}
\hline Scientific name & Common name & Substance & $\begin{array}{l}\text { No. with } \\
\text { residues }\end{array}$ & $\begin{array}{r}\text { Range of } \\
\text { residues in } \\
\text { liver, } \mathrm{mg} / \mathrm{kg}\end{array}$ & Reference \\
\hline Meles meles & Badger & Bromadiolone & 1 & 0.9 & Berny et al. 1997 \\
\hline Mephitidae sp. & Skunk & Bromadiolone & 3 & $0.02-0.28$ & Stone et al. 1999 \\
\hline Milvus migrants & Black kite & Bromadiolone & 5 & $0.3-0.6^{2}$ & Berny et al. 1997 \\
\hline Milvus milvus & Red kite & & 23 & & Walker et al. 2008b \\
\hline Mustela erminea & Stoat & Brodifacoum & 31 & $0.05-1.52$ & Murphy et al. 1998 \\
\hline Mustela erminea & Stoat & Bromadiolone & 3 & $0.04-0.38$ & McDonald et al. 1998 \\
\hline Mustela erminea & Stoat & Brodifacoum & 1 & 0.12 & McDonald et al. 1998 \\
\hline Mustela erminea & Stoat & Brodifacoum & 9 & & Alterio 1996 \\
\hline Mustela erminea & Stoat & Brodifacoum & 11 & & Alterio et al. 1997 \\
\hline Mustela erminea & Stoat & Brodifacoum & 98 & $0.008-1.32$ & Eason et al. 2002 \\
\hline Mustela furo & Feral ferret & Brodifacoum & 9 & & Murphy et al. 1998a \\
\hline Mustela furo & Feral ferret & Brodifacoum & 5 & & Alterio 1996 \\
\hline Mustela lutreola & European mink & Bromadiolone & 1 & 5 & $\begin{array}{l}\text { Fournier-Chambrillon } \\
\text { et al. } 2004\end{array}$ \\
\hline Mustela nivalis & Weasel & Brodifacoum & 10 & & Murphy et al. 1998a \\
\hline Mustela nivalis & Weasel & Bromadiolone & 1 & 0.25 & McDonald et al. 1998 \\
\hline Mustela nivalis & Weasel & Brodifacoum & 1 & & Alterio et al. 1997 \\
\hline Mustela putorius & Polecat & Bromadiolone & 5 & & $\begin{array}{l}\text { Fournier-Chambrillon } \\
\text { et al. } 2004\end{array}$ \\
\hline Mustela putorius & Polecat & Difenacoum & 1 & 1.4 & Fletcher et al. 1994 \\
\hline Mustela putorius & Polecat & Difenacoum & 2 & $0.3-1.4$ & Birks 1998 \\
\hline Mustela putorius & Polecat & & 31 & & $\begin{array}{l}\text { Shore et al. 1996; } \\
\text { 1999; } 2003\end{array}$ \\
\hline Mustela vison & American mink & Bromadiolone & 3 & $1.9-4.2$ & $\begin{array}{l}\text { Fournier-Chambrillon } \\
\text { et al. } 2004\end{array}$ \\
\hline Otus asio & Screech owl & Brodifacoum & 9 & $0.007-0.8$ & $\begin{array}{l}\text { Hegdal \& Colvin, } \\
1988\end{array}$ \\
\hline Otus asio & Screech owl & Brodifacoum & 2 & $0.34-0.8$ & Stone et al. 1999 \\
\hline Otus asio & Screech owl & & 10 & & Stone et al. 2003 \\
\hline Puma concolor & Mountain lion & & 4 & & Riley et al. 2007 \\
\hline Procyon lotor & Raccoon & Brodifacoum & 6 & $0.32-5.3^{2}$ & Stone et al. 1999 \\
\hline Strix aluco & Tawny owl & & 33 & & Walker et al. 2008 \\
\hline Strix aluco & Tawny owl & Bromadiolone & 2 & & Lambert et al. 2007 \\
\hline Strix varia & Barred owl & & 3 & & Stone et al. 2003 \\
\hline Sus scrofa & Wild boar & Bromadiolone & 3 & $0.4-3.6$ & Berny et al. 1997 \\
\hline Sus scrofa & Wild boar & Brodifacoum & 21 & $0.007-1.78$ & Eason et al. 2002 \\
\hline Tyto alba & Barn owl & & 124 & & Walker et al. 2008 \\
\hline Tyto alba & Barn owl & Brodifacoum & 15 & $0.019-0.515$ & Newton et al. 1990 \\
\hline Tyto alba & Barn owl & Difenacoum & 15 & $0.005-0.106$ & Newton et al. 1990 \\
\hline Tyto alba & Barn owl & & 132 & & Newton et al. 1997 \\
\hline Tyto alba & Barn owl & & 187 & & Newton et al. 1999 \\
\hline Tyto alba & Barn owl & Bromadiolone & 4 & & Lambert et al. 2007 \\
\hline Tyto alba & Barn owl & Difenacoum & 5 & & Lambert et al. 2007 \\
\hline Tyto alba & Barn owl & Difenacoum & 16 & & Shore et al. 2006 \\
\hline Tyto alba & Barn owl & Bromadiolone & 15 & & Shore et al. 2006 \\
\hline Tyto alba & Barn owl & Brodifacoum & 3 & & Shore et al. 2006 \\
\hline Vulpes vulpes & Red fox & Bromadiolone & 22 & $0.8-6.9^{2}$ & Berny et al. 1997 \\
\hline Vulpes vulpes & Red fox & Brodifacoum & 2 & $1.32-4.01$ & Stone et al. 1999 \\
\hline
\end{tabular}

${ }^{1}$ Residue from plasma

${ }^{2}$ Whole-carcass residues 
Table 2. Secondary exposure studies made in controlled circumstances. Time after exposure stands for the time after which animals have died in poisoning. Also survivers displayed signs of haemorrhage in majority of studies.

\begin{tabular}{|c|c|c|c|c|c|}
\hline Scientific name & Common name & $\begin{array}{l}\text { No dead } I \\
\text { No tested }\end{array}$ & Substance & $\begin{array}{r}\text { Time after } \\
\text { exposure, } \\
\text { days }\end{array}$ & Reference \\
\hline Aquila chrysaetos & Golden eagle & $0 / 4$ & Brodifacoum & 4 & Marsh \& Howard 1978 \\
\hline Arvicola terrestris & Water vole & 1 & Bromadiolone & 135 & Sage et al. 2008 \\
\hline Buteo buteo & Eurasian buzzard & $4 / 5$ & Brodifacoum & 6 & Lutz 1987 \\
\hline Buteo buteo & Eurasian buzzard & $3 / 40$ & Bromadiolone & 3 & Grolleau et al. 1989 \\
\hline Buteo buteo & Eurasian buzzard & $3 / 4$ & Bromadiolone & 10 & Lutz 1986 \\
\hline $\begin{array}{l}\text { Buteo jamaicen- } \\
\text { sis }\end{array}$ & Red-tailed hawk & $4 / 4$ & Brodifacoum & 4 & Marsh \& Howard 1978 \\
\hline Buteo lineatus & $\begin{array}{l}\text { Red-shouldered } \\
\text { hawk }\end{array}$ & $2 / 2$ & Brodifacoum & 4 & Marsh \& Howard 1978 \\
\hline Canis latrans & Coyote & $2 / 7$ & Bromadiolone & 5 & Marsh \& Howard 1986 \\
\hline $\begin{array}{l}\text { Canis lupus } \\
\text { familiaris }\end{array}$ & Dog (domestic) & $1 / 6$ & Brodifacoum & $1-4$ & Erickson \& Urban 2004 \\
\hline $\begin{array}{l}\text { Circus approxi- } \\
\text { mans }\end{array}$ & $\begin{array}{l}\text { Australasian } \\
\text { harrier }\end{array}$ & $1 / 4$ & Brodifacoum & & $\begin{array}{l}\text { Godfrey } 1985 \text {; Williams } \\
\text { et al. } 1986\end{array}$ \\
\hline Corvux caurinus & Nothwestern crow & 3 & Brodifacoum & 12 & Howald et al. 1999 \\
\hline Falco sparverius & American kestrel & $9 / 18$ & Brodifacoum & $5-6$ & $\begin{array}{l}\text { Savarie \& LaVoie 1979; } \\
\text { LaVoie } 1990\end{array}$ \\
\hline $\begin{array}{l}\text { Herpestes auro- } \\
\text { punctatus }\end{array}$ & Mongoose & $1 / 4$ & Brodifacoum & 10 & Pank \& Hirata 1976 \\
\hline $\begin{array}{l}\text { Herpestes auro- } \\
\text { punctatus }\end{array}$ & Mongoose & $3 / 4$ & Bromadiolone & 6 & Pank \& Hirata 1976 \\
\hline Larus atricilla & Laughing gull & $5 / 5$ & Brodifacoum & 5 & Erickson \& Urban 2004 \\
\hline Larus atricilla & Laughing gull & $4 / 5$ & Brodifacoum & 5 & Erickson \& Urban 2004 \\
\hline Mustela erminea & Stoat (ermine) & $1 / 11$ & Bromadiolone & $3-5$ & Grolleau et al. 1989 \\
\hline Mustela erminea & Stoat & 11 & Brodifacoum & $6-9$ & Alterio et al. 1997 \\
\hline Tyto alba & Barn owl & $4 / 8$ & Bromadiolone & $5-7$ & Lee 1994,1995 \\
\hline Tyto alba & Barn owl & $3 / 4$ & Flocoumafen & & Lee 1995 \\
\hline Tyto alba & Barn owl & $1 / 9$ & Bromadiolone & $6-10$ & $\begin{array}{l}\text { Mendenhall \& Pank } \\
\text { 1980; Wyllie } 1995\end{array}$ \\
\hline Tyto alba & Barn owl & $9 / 12$ & Brodifacoum & $3-8$ & $\begin{array}{l}\text { Mendenhall \& Pank } \\
\text { 1980; Newton et al. } \\
1990\end{array}$ \\
\hline Tyto alba & Barn owl & $4 / 8$ & Brodifacoum & $5-7$ & Lee,1994, 1995 \\
\hline Tyto alba & Barn owl & $1 / 4$ & Brodifacoum & 15 & Gray et al. 1994 \\
\hline Tyto alba & Barn owl & $1 / 6$ & Difenacoum & $6-10$ & $\begin{array}{l}\text { Mendenhall \& Pank } \\
1980\end{array}$ \\
\hline $\begin{array}{l}\text { Vulpes vulpes/ } \\
\text { Urocyon } \\
\text { cinereoargenteus }\end{array}$ & $\begin{array}{l}\text { Red fox and grey } \\
\text { fox }\end{array}$ & $2 / 5$ & Brodifacoum & 4 & Erickson \& Urban 2004 \\
\hline
\end{tabular}

